\title{
Ticks (Acari: Ixodidae) as ectoparasites of Brazilian wild birds and their association with rickettsial diseases
}

\section{Carrapatos (Acari: Ixodidae) como ectoprasitos de aves Brasileiras e sua associação com doenças riquetsiais}

\author{
Maria OGRZEWALSKA ${ }^{1}$; Adriano PINTER ${ }^{2}$ \\ ${ }^{1}$ Fundação Oswaldo Cruz, Instituto Oswaldo Cruz, Laboratório de Hantaviroses e Rickettsioses, Rio de Janeiro - RJ, Brazil \\ ${ }^{2}$ Superintendência de Controle de Endemias Sucen, Laboratório de Bioquímica e Biologia Molecular, São Paulo - SP, Brazil
}

\begin{abstract}
Ticks (Acari: Ixodidae) are obligatory hematophagous ectoparasites of a variety of vertebrate hosts and play an important role in the transmission and ecology of infectious pathogens causing diseases in humans and animals worldwide. Sixty-eight species of ticks exist in Brazil, and at least 23 are found parasitizing wild birds. This number is increasing with the advent of new studies highlighting the underestimated role of birds in the life cycle of these arthropods. In South America, many of these ticks are involved in epidemiology of the life-threatening spotted fever diseases caused by bacteria from the genus Rickettsia (Rickettsiales: Rickettsiaceae). The aim of this paper is to present up-to-date knowledge about the bird-tick fauna of Brazil and their association with rickettsioses. The available literature concerning ticks on birds and tick-borne diseases related to these ticks in Brazil has been revised. It could be concluded that birds play a primary role in life cycles of various tick species, especially during immature stages (larvae and nymphs). The best known is a bird-tick fauna from the Atlantic Forest and from Brazilian savannah called Cerrado in southern and central Brazil, respectively. On the other hand, the knowledge about bird tick parasitism from other Brazilian biomes such as the Amazon, Caatinga, Pantanal and Pampas regions is very scarce and requires further study. Moreover, no studies about the role of birds as mobile hosts for spreading ticks to new areas exist, nor has their role in the natural life cycle of Rickettsia been thoroughly examined.
\end{abstract}

Keywords: Ticks. Ectoparasites. Rickettsia. Disease. Birds. Brazil.

\section{Resumo}

Os carrapatos (Acari: Ixodoidea) são ectoparasitas obrigatórias de uma variedade de hospedeiros vertebrados e têm um papel importante na ecologia e transmissão de diversos patógenos causadores de doenças em humanos e animais no mundo todo. No Brasil existem 68 espécies de carrapatos e pelo menos 23 espécies são encontradas parasitando aves silvestres. Esse número tem crescido com o advento de novos estudos ressaltando o papel das aves nos ciclos de vida desses artrópodes. Na América do Sul alguns desses carrapatos estão envolvidos na epidemiologia de doenças graves para o ser humano, como a febre maculosa, causada por bactérias do gênero Rickettsia (Rickettsiales: Rickettsiaceae). O alvo desse artigo é apresentar o estado atual de conhecimento sobre a fauna de carrapatos encontrados em aves no Brasil e as associações estabelecidas com as riquetsioses. A literatura disponível sobre carrapatos em aves e ocorrência de riquétsias foi revisada e pôde ser concluído que aves têm um papel importante nos ciclos de vida de várias espécies de carrapatos, sendo especialmente importantes para os estágios imaturos (larvas e ninfas). A maior parte do conhecimento sabrecai na fauna de carrapatos de aves dos biomas Mata Atlântica e Cerrado no sudeste e centro-oeste do Brasil. Já o conhecimento sobre o parasitismo por carrapatos em aves dos outros biomas: Amazônia, Caatinga, Pantanal e Pampas é muito limitado. Além disso, não há estudos sobre o papel de aves como disseminadores de carrapatos entre áreas e também o papel de aves no ciclo de Rickettsia não está totalmente esclarecido.

Palavras-chave: Carrapatos. Ectoparasitas. Rickettsia. Doença. Aves. Brasil. 
Correspondence to:

Maria Ogrzewalska

Fundação Oswaldo Cruz, Instituto Oswaldo Cruz, Laboratório de Hantaviroses e Rickettsioses

Av. Brasil, 4365

CEP 21040-360, Rio de Janeiro, RJ, Brazil

e-mail: maria.ogrzewalska@ioc.fiocruz.br

Received: $17 / 07 / 2015$

Approved: 06/02/2016

\section{Introduction}

Ticks (Acari: Ixodidae) are blood-feeding ectoparasites of wild and domestic terrestrial or semi-aquatic vertebrates. Ticks have a worldwide distribution and are capable of transmitting a broad range of human and animal pathogens. Currently the Brazilian tick fauna is represented by 68 species, 46 in the Ixodidae family and 22 in the Argasidae family (ARAGÃO 1936; DANTASTORRES et al., 2009a, 2012; LABRUNA; VENZAL 2009; NAVA et al., 2010a; 2014; BARROSBATTESTI et al., 2015; KRAWCZAK et al., 2015). In Brazil, several species of ticks representing genera Ornithodoros, Ixodes, Amblyomma, and Haemaphysalis have been found parasitizing wild birds; however, insight derived from the latest investigations suggest that the Brazilian bird tick fauna is probably much more diverse than presently known. The recent increase in studies on ticks parasitizing birds is related with: (i.) Advent of molecular methods for identification of immature stages, especially larvae by amplifying fragments of mainly of 16S RNA gene (MANGOLD et al., 1998) and/or 12S RNA gene (BEATI; KEIRANS, 2001) and comparing the obtained sequences with those available in GenBank; (ii) Publication of identification key for nymphs of Amblyomma - the most commonly found genera on birds in Brazil (MARTINS et al., 2010). Before that, the only solution was to identify larvae and nymph of Amblyomma by rearing them on rabbits to adult stages (LABRUNA et al., 2002a; SZABÓ et al., 2007a,b;
2009; OGRZEWALSKA et al., 2009a), although this method was not very efficient, especially for larvae that usually died before reaching the adult stage.

About $60 \%$ of the bird species documented for South America are found in Brazil. Currently, 1,901 species (PIACENTINI et al., 2015) are registered, but this number is still increasing almost every year. This is due to new occurrences or new species being described, like a spectacular discovery of 15 new species in 2013 in Brazilian Amazon (DEL HOYO et al., 2013). Although Brazilian ornitofauna is rich and diverse, the involvement of wild birds in the epidemiology of diseases is poorly known. Most research investigating bird diseases focuses on viral zoonosis in direct contact with poultry, viral diseases affecting industrial aviculture or possible transmission of viruses by migratory birds, such as Avian influenza (ARAUJO et al., 2014), Newcastle Disease Virus (CUNHA; SILVA, 1955; OLIVEIRA et al., 2000; ORSI et al., 2010; THOMAZELLI et al., 2012), West Nile virus (OMETTO et al., 2013), Avian Bornavirus (ENCINAS-NAGEL et al., 2014) and little is known about the role of birds as disseminators of potentially infected ectoparasites such ticks or their role as potential reservoirs of pathogens harbored and transmitted by ticks. Outside of Brazil, mainly in Europe and North America, the role of birds as hosts and disseminators of ectoparasites such as ticks have been broadly studied. Birds were shown to be important mobile hosts responsible for the spread of one or more stages of ticks and tick-borne 
pathogens such as Rickettsia, Borrelia, Anaplasma and Ehrlichia (ANDERSON et al., 1896; PARKER et al., 1933; HOOGSTRAAL, 1961; 1963; SOMOV; SOLDATOV, 1964 apud HUBÁLEK 2004; OLSEN et al., 1993; GERN et al., 1998; HUMAIR et al., 1998; ALEKSEEV et al., 2001; BJÖERSDORFF et al., 2001; DANIELS et al., 2002; SANTOS-SILVA et al., 2006; SMITH et al., 2006; OGDEN et al., 2008; HAMER et al., 2011; GELLER et al., 2013; NORTE et al., 2013; LITERAK et al., 2015). Migratory birds in particular have received much attention as they can transport potentially infected ticks across large areas and may account for the origin of some new foci of diseases (ANDERSON et al., 1986; OLSEN et al., 1995a; KLICH et al., 1996; SMITH et al., 1996; RAND et al., 1998; KINSEY et al., 2000; SCOTT et al., 2001, 2010, 2012; JONGEJAN et al., 2004; MORSHED et al., 2005; DUBSKA et al., 2009; ELFVING et al., 2010; HILDEBRANDT et al., 2010; KJELLAND et al., 2010; HASLE et al., 2011; HASLE, 2013; MOVILA et al., 2011; GELLER et al., 2013; CAPLIGINA et al., 2014), even introducing them to different continents (OLSEN et al., 1995b; MUKHERJEE et al., 2014; SCOTT; DURDEN, 2015). Although the role of birds as hosts and disseminators of ticks has received much attention over the past several years, there is a lack of studies in South America, including Brazil. The aim of this review is to present up-to-date knowledge about the bird-tick fauna of Brazil and their association with rickettsioses.

\section{Ticks found parasitizing birds in Brazil}

\section{Family Argasidae}

Argas (Persicargas) miniatus Koch 1844. It is the only species representing the genera Argas in Brazil, until now only found on domestic fowls (LOUREIRO, 1966; EVANS et al., 2000; ARZUA et al., 2005; LOROSA et al., 2007). No records of human parasitism exist.
Ornithodoros mimon Kohls, Clifford and Jones 1969 parasitizes bats (Chiroptera) in Bolivia, Uruguay, Argentina and Brazil (KOHLS et al., 1969; VENZAL et al., 2004a; BARROSBATTESTI et al., 2006; LABRUNA et al., 2014). Larvae were found parasitizing small mammals from the order Didelphimorphia and Rodentia collected in woodland fragments of Cerrado in the Mato Grosso do Sul, Brazil (SPONCHIADO et al., 2015). Recently, a few larvae were collected from wild Passeriformes birds in Mato Grosso (RAMOS et al., 2015). This species is aggressive to humans; however, its role in tick-borne diseases is still unknown (BARROS-BATTESTI et al., 2011; LANDULFO et al., 2012; LABRUNA et al., 2014).

Ornithodoros sp. The sole larva has been also reported on swift Streptoprocne zonaris (Shaw, 1796) (Apodiformes) captured in Minas Gerais State (TOLESANO-PASCOLI et al., 2014).

\section{Family Ixodidae}

Amblyomma aureolatum (Pallas, 1772). Distribution of $A$. aureolatum is restricted to the eastern area of South America, from Uruguay to Surinam, including northeastern Argentina, eastern Paraguay, southeastern to southern Brazil, and French Guiana (GUGLIELMONE et al., 2003). This tick species is typical of the Atlantic rainforest region, where it finds optimal conditions of high humidity and cool temperatures (PINTER et al., 2004; SZABÓ et al., 2009). Adults of A. aureolatum in natural conditions feed mainly on wild carnivore species, such as foxes Cerdocyon thous (Linnaeus, 1766) and Lycalopex spp. and raccoons Procyon cancrivorus (Cuvier, 1798) (GUGLIELMONE et al., 2003, LABRUNA et al., $2005 \mathrm{~b}$ ), but in the rural areas close to rainforest remnants, adult ticks feed mainly on domestic dogs (PINTER et al., 2004; MORAES-FILHO et al., 2009; OGRZEWALSKA et al., 2012a). Only a few host records have been reported for the immature stages (larvae and nymphs) of A. aureolatum, 
including wild birds in southern Brazil (ARZUA et al., 2003; GUGLIELMONE et al., 2003; OGRZEWALSKA et al., 2012a; PACHECO et al., 2012), Uruguay (VENZAL et al., 2005), Paraguay (OGRZEWALSKA et al., 2014), and a few rodent species from families Echimyidae, Ctenomyidae, and Bradypodidae (GUGLIEMONE et al., 2003; 2014). This species is involved in the epidemiology of Brazilian spotted fever in Brazil transmitting to humans Rickettsia rickettsii. Moreover, Brazilian spotted fever has been found to be infected by Rickettsia bellii, (PINTER; LABRUNA, 2006; MORAES-FILHO et al., 2009; OGRZEWALSKA et al., 2012a).

Amblyomma auricularium (Conil, 1878). This species has been found from northern Patagonia in Argentina throughout the Neotropics into the Nearctic region to southern USA (Texas, Florida), with records also from Belize, Bolivia, Brazil, Colombia, Costa Rica, French Guiana, Honduras, Mexico, Nicaragua, Panama, Paraguay, Trinidad and Tobago, Uruguay and Venezuela (GUGLIELMONE et al., 2014). Within its distribution area, all parasitic stages of $A$. auricularium are found feeding mainly on armadillos (Dasypodidae), although immature stages are also found feeding on small rodents (GUGLIELMONE et al., 2003; HORTA et al., 2011). However, Lugarini et al. (2015) recently found various immature stages (17 nymphs, 14 larvae) parasitizing birds sampled at a coastal Atlantic forest in Paraíba State and the xeric shrubland at Caatinga biome in Bahia State, Brazil. Although A. auricularium is not known to be a vector of pathogens causing diseases in humans or animals and no report of human infestation by these tick exists, it is important to point out that this species was recently found to be infected with 'Candidatus Rickettsia amblyommii' and $R$. bellii (SARAIVA et al., 2013; LUGARINI et al., 2015).

Amblyomma brasiliense Aragão 1908 occurs in Brazil, Argentina and Paraguay
(GUGLIELMONE et al., 2014). Under natural conditions, peccaries (Tayassu spp.) are considered the primary hosts for $A$. brasiliense ticks (ARAGÃO, 1936). However, this tick is also aggressive to humans (GUGLIELMONE et al., 2006). Although scarce records on parasitism of ground-dwelling birds (BARROS-BATTESTI et al., 2006) exist in literature, birds are rather accidental hosts and seem not to play an important role in the life cycle of this species.

Amblyomma cajennense complex. Currently, A. cajennense is a complex of six species, $A$. cajennense sensu stricto (s.s) Fabricius, 1787, Amblyomma tonelliae Nava, Beati and Labruna (2014), Amblyomma interandinum Beati, Nava and Cáceres (2014), Amblyomma patinoi Labruna, Nava and Beati (2014), Amblyomma mixtum Koch, 1844 and Amblyomma sculptum Berlese, 1888 (BEATI et al., 2013; NAVA et al., 2014). In Brazil, two species are found: A. sculptum in coastal and central-western states of Brazil and $A$. cajennense s.s in the Amazonian region of South America. Adults are found on variety of animals; however, capybaras (Hydrochoerus hydrochaeris (Linnaeus, 1766), tapirs (Tapirus terrestris (Linnaeus, 1758)), peccaries (Tayassu spp.) and horses (Equus caballus Linnaeus, 1758) serve as main primary hosts for these ticks. Records of $A$. cajennense parasitizing birds in Brazil exist in literature; however, taking into account the recent A. cajennense complex division, almost all available records probably refer to A. sculptum (LABRUNA et al., 2007a; TEIXEIRA et al., 2008; OGRZEWALSKA et al., 2009a; 2011a; SANTOLIN et al., 2012; SILVEIRA et al., 2015; TOLESCANOPASCOAL et al., 2014; RAMOS et al., 2015). Still, birds are considered accidental hosts, as even in areas where this tick is extremely abundant, birds are rarely found parasitized by this species (OGRZEWALSKA et al., 2011b). In Brazil, A. sculptum is a very aggressive tick to humans and the main vector of $R$. rickettsii to humans causing 
the lethal disease known as Brazilian spotted fever (SZABÓ et al., 2013a; KRAWCZAK et al., 2014).

Amblyomma calcaratum Neumann, 1899 has been reported from Mexico to Argentina, where the adult stage is found feeding almost exclusively on anteaters (Myrmecophagidae) (JONES et al., 1972; CÀCERES et al., 2002; GUGLIELMONE et al., 2014; WITTER et al., 2016), but has also been found sporadically on other mammals: raccoon $P$. cancrivorus, sloths Choloepus hoffmanni Peters, 1858 and deer Mazama americana Erxleben, 1777. Although immature stages have been found on tapirs and anteaters (GUGLIELMONE et al., 2014), it seems that wild birds play important role in the life cycle of this species. In Brazil, A. calcaratum, mainly nymphs, have been found parasitizing birds in the region of the Atlantic Forest in the state of Paraná (PACHECO et al., 2012), São Paulo (LABRUNA et al., 2007a; OGRZEWALSKA et al., 2009a; 2011a; SANCHES et al., 2013), Bahia (OGRZEWALSKA et al., 2011a), a region of the Amazon Forest in the state of Pará (OGRZEWALSKA et al., 2010) and Amazonas (MARTINS et al., 2014b), the region of Pantanal in the state of Mato Grosso (RAMOS et al., 2015) and Cerrado in the state of Mato Grosso (RAMOS et al., 2015) and Mato Grosso do Sul (OGRZEWALSKA et al., 2013). Moreover, this species was found parasitizing wild birds in Peru (OGRZEWALSKA et al., 2012b), Paraguay (OGRZEWALSKA et al., 2014) and Costa Rica (OGRZEWALSKA et al., 2015). Amblyomma calcaratum is a species of potential medical importance because a spotted fever group bacterium, identified as Rickettsia parkeri-like agent, was recently reported infecting nymphs collected from birds in Brazil (OGRZEWALSKA et al., 2013). According to literature, this species has been found infesting humans (GUGLIELMONE et al., 2014).

Amblyomma coelebs Neumann, 1899 is established in the Neotropical and Nearctic regions (GUGLIELMONE et al., 2014). Adults almost exclusively parasitize tapirs (Tapirus sp.) (LABRUNA et al., 2010), but they are also periodically collected on other wild and domestic even-toed ungulates Artiodactyla (LABRUNA et al., 2005a). These ticks are frequently collected on vegetation and attached to humans (GUGLIELMONE et al., 2006). Few records of parasitism of immature stages exist; however, immature stages seem to have a broad range of hosts and have been found in Rodentia (MARTINS et al., 2011; MARTINS et al., 2014a; SPONCHIADO et al., 2015; WITTER et al., 2016), Didelphimorphia (LABRUNA et al., 2005a; SARAIVA et al., 2012; SPONCHIADO et al., 2015; WITTER et al., 2016), Cingulata (MARTINS et al., 2014a), Artiodactyla (LABRUNA et al., 2005a, 2010), Carnivora (LABRUNA et al., 2002a; 2005b; MARTINS et al., 2011; WITTER et al., 2016) and on humans (LABRUNA et al., 2005a; GARCIA et al., 2015). Although few records of immature $A$. coelebs exist in Brazil (OGRZEWALSKA et al., 2009a, 2010) and in Costa Rica (OGRZEWALSKA et al., 2015), birds are rather accidental host for this species. Ticks A. coelebs were shown to be infected with ' $\mathrm{Ca}$. Rickettsia amblyommii' in Brazil (LABRUNA et al., 2004a; SILVEIRA et al., 2015; WITTER et al., 2016) and French Guyana (PAROLA et al., 2007).

Amblyomma dissimile Koch, 1844 occurs in the Nearctic, Neotropical zoogeographic regions. Usual hosts of larvae, nymphs and adult ticks are amphibians (Anura, Bufonidae) and reptiles (Squamata: Boidae and Iguanidae). Infestations by A. dissimile on mammalian hosts, including humans, have occasionally been reported (GUGLIELMONE et al., 2014). Birds are considered exceptional hosts for this tick. In Brazil, only one record exists of $A$. dissimile nymph infesting a macaw, Primolius maracana Vieillot, 1816 held in captivity (SCOFIELD et al., 2011). In Colombia, A. dissimile ticks have been 
found infected with Rickettsia sp. strain colombianensi (MIRANDA et al., 2012).

Amblyomma geayi Neumann, 1899 is a Neotropical species. Principal hosts for adults are the sloths Bradypus tridactylus Linnaeus, 1758 and C. hoffmanni (Xenarthra, Pilosa, Folivora) but a few collections were taken from the porcupine Coendou prehensilis Linnaeus, 1758 (Rodentia, Erethizontidae). Human infestation is unknown (GUGLIELMONE et al., 2014). A few nymphs were collected on sloths Bradypus variegatus Schinz, 1825 (MARTINS et al., 2013) and on opossum (Didelphidae) (GUGLIELMONE et al., 2014). Although only a few records of parasitism of immature stages on wild birds exist, it was suggested that passeriform birds may play an important role in the life cycle of tick species in the Amazon forest region (OGRZEWALSKA et al., 2010; MARTINS et al., 2014b). Ticks collected form wild birds in the state of Pará have been found infected with ' $\mathrm{Ca}$. Rickettsia amblyommii' (OGRZEWALSKA et al., 2010).

Amblyomma humerale Koch, 1844 is a Neotropical species. Usual hosts for adult ticks are tortoises Chelonoidis (Testudinidae) and mammals are considered exceptional hosts (LABRUNA et al., 2002b, 2005a; MARTINS et al., 2014a). Human infestation is unknown (GUGLIELMONE et al., 2014). Few records for immature stages exist. Nymphs were collected in lizards Plica Linnaeus, 1758, Plica umbra Linnaeus, 1758, Kentropyx calcarata Spix, 1825, anteater Cyclopes didactylus Linnaeus, 1758 and D. marsupialis (LABRUNA et al., 2002b, 2005a; WITTER et al., 2016) and armadillo (Cingulata) (MARTINS et al., 2014a; WITTER et al., 2016) and caiman Paleosuchus trigonatus (Schneider, 1801), coati Nasua nasua (Linnaeus, 1766) and anteater Tamandua tetradactyla (Linnaeus, 1758) (WITTER et al., 2016). It was recently suggested that wild birds may play an important role in the life cycle serving as hosts for larvae and nymphs of this species in the Amazon forest region, State of Pará (OGRZEWALSKA et al., 2010; MARTINS et al., 2014b). Adult A. humerale were shown to be infected with $R$. bellii in Brazil (LABRUNA et al., 2004a).

Amblyomma longirostre Koch, 1844 is widely distributed throughout the Neotropical region (JONES et al., 1972; GUGLIELMONE et al., 2014; reviewed by NAVA et al., 2010b; NOVAKOVA et al., 2015). Known human infestation is scarce (ARZUA et al., 2005; GUGLIELMONE et al., 2006). The adult stage feeds primarily on rodents Coendou, Chaetomys and Sphiggurus (Erethizontidae) (JONES et al., 1972; LABRUNA et al., 2002a; 2004c; BARROS-BATTESTI et al., 2006; SILVEIRA et al., 2008; reviewed by NAVA et al., 2010b). Birds are the main host for immature stages and in Brazil it is the most prevalent species found on birds (ARAGÃO, 1936; LABRUNA et al., 2007a; SOARES et al., 2009; OGRZEWALSKA et al., 2008, 2009a, 2010, 2011a, 2012a; TOLESANOPASCOLI et al., 2010; NAVA et al., 2010b; LUZ et al., 2012; LUGARINI et al., 2015; RAMOS et al., 2015; GRESSLER et al., 2016; WITTER et al., 2016). All stages (adults, nymphs and larvae) have been found infected with ' $C a$. R. amblyommii' or bacteria closely related to it (LABRUNA et al., 2004a; OGRZEWALSKA et al., 2008, 2010, 2011a, 2012a, 2015; MEDEIROS et al., 2011; PACHECO et al., 2012; LUGARINI et al., 2015; RAMOS et al., 2015; NOVAKOVA et al., 2015; Table1). Relevant association between species of birds are presented elsewhere (LUZ; FACCINI, 2013). 
Table 1 - Rickettsia species found in immature Amblyomma ticks collected on Brazilian wild birds

\begin{tabular}{|c|c|c|c|c|}
\hline Rickettsia species & Tick species & State & Bioma & Reference \\
\hline \multirow[t]{2}{*}{ Rickettsia bellii } & $\begin{array}{l}\text { Amblyomma } \\
\text { auricularium }\end{array}$ & $\mathrm{BA}$ & Caatinga & Lugarini et al., 2015 \\
\hline & Amblyomma nodosum & SP & Atlantic forest & Ogrzewalska et al., 2009b \\
\hline 'Candidatus Rickettsia andenae' & Amblyomma parvum & BA & Caatinga & Lugarini et al., 2015 \\
\hline \multirow[t]{10}{*}{$\begin{array}{l}\text { 'Candidatus Rickettsia amblyommii' } \\
\text { or closely related strains }\end{array}$} & $\begin{array}{l}\text { Amblyomma } \\
\text { auricularium }\end{array}$ & $\mathrm{BA}$ & Caatinga & Lugarini et al., 2015 \\
\hline & Amblyomma geayi & PA & Amazon & Ogrzewalska et al., 2010 \\
\hline & Amblyomma longirostre & BA & Atlantic Forest & Ogrzewalska et al., 2011a \\
\hline & & MT & $\begin{array}{l}\text { Pantanal and } \\
\text { Cerrado }\end{array}$ & Ramos et al., 2015 \\
\hline & & $\mathrm{PB}$ & Atlantic Forest & Lugarini et al., 2015 \\
\hline & & PA & Amazonia & Ogrzewalska et al., 2010 \\
\hline & & PR & Atlantic Forest & Pacheco et al., 2012 \\
\hline & & SP & Atlantic Forest & Ogrzewalska et al., 2008, 2012a \\
\hline & Amblyomma nodosum & SP & Atlantic Forest & this paper \\
\hline & Amblyomma varium & SP & Atlantic Forest & this paper \\
\hline \multirow[t]{8}{*}{ Rickettsia parkeri-like strains } & Amblyomma calcaratum & MS & Cerrado & Ogrzewalska et al., 2013 \\
\hline & Amblyomma longirostre & PR & Atlantic forest & Pacheco et al., 2012 \\
\hline & Amblyomma nodosum & MT & Cerrado & Ramos et al., 2015 \\
\hline & & $\mathrm{PB}$ & Atlantic forest & Lugarini et al., 2015 \\
\hline & & SP & Atlantic forest & Ogrzewalska et al., 2009b \\
\hline & Amblyomma parkeri & PR & Atlantic forest & Pacheco et al., 2012 \\
\hline & & SP & Atlantic forest & Ogrzewalska et al., 2012a \\
\hline & $\begin{array}{l}\text { Amblyomma } \\
\text { haplotype Nazare }\end{array}$ & SP & Atlantic forest & Ogrzewalska et al., 2012a \\
\hline
\end{tabular}

Amblyomma naponense (Packard, 1869) is a Neotropical tick species. Usual hosts of adult ticks are peccaries (Tayassuidae). It is known to parasitize humans (GUGLIELMONE et al., 2006). Little is known about hosts for immature stages. Nymphs were found in Brazil on C. thous and T. tajacu captured in Emas National Park, Goiás State, Brazil (MARINS et al., 2011). Regarding birds, only three sporadic records exist of parasitism of nymphs in the southeastern part of Brazil (OGRZEWALSKA et al., 2009a).

Amblyomma nodosum Neumann, 1899 is a Neotropical tick species widely distributed throughout South and Central America. No known human infestation records exist (GUGLIELMONE et al., 2014). The adults of this species are commonly found in the anteaters (Xenarthra, Pilosa) (ARAGÃO, 1936; JONES et al., 1972; BECHARA et al., 2002; LABRUNA et al., 2002a; DANTAS-TORRES et al.,
2010; MARTINS et al., 2014a). Subadults, especially nymphs, seem to feed primarily on birds (JONES et al., 1972; LABRUNA et al., 2007a; OGRZEWALSKA et al., 2009a, 2011a, 2012a; TOLESANO-PASCOLI et al., 2010; LUZ et al., 2012; MARTINS et al., 2013; PASCOAL et al., 2013; TORGA et al., 2013; LUGARINI et al., 2015; NOVAKOVA et al., 2015; RAMOS et al., 2015; WITTER et al., 2016). Ogrzewalska et al. (2011b) found higher prevalence of A. nodosum on wild birds in smaller and degraded forest fragments of Atlantic Forest in the interior of the São Paulo State than in preserved, more humid fragments. In Brazil, immature stages collected on wild birds have been found infected with Rickettsia parkeri-like agent (OGRZEWALSKA et al., 2009b; LUGARINI et al., 2015; RAMOS et al., 2015), R. bellii (OGRZEWALSKA et al., 2009b). Two nymphs of $A$. nodosum collected from Thamnophilus doliatus (Linnaeus, 1764) and Herpsilochmus longirostris 
Pelzeln, 1868 (Passeriformes, Thamnophilidae) in Dracena, SP, were infected with ' $\mathrm{Ca}$. Rickettsia amblyommii', identical with strain AL (verbal information) (Table 1). Adults were recently found infected with undefined Rickettsia sp (ALMEIDA et al., 2012) and also with Rickettsia parkeri-like agent (WITTER et al., 2016).

Amblyomma ovale Koch, 1844 occurs in Nearctic and Neotropical zoogeographic regions. Adults mainly parasitize carnivores (LABRUNA et al., 2005b; WITTER et al., 2016), and domestic dogs (SABATINI et al., 2010; SZABÓ et al., 2013b). The tick is aggressive to humans (GUGLIELMONE et al., 2006; SZABÓ et al., 2006, 2013b). The main hosts for immature stages are rodents, especially Echimyidae (SARAIVA et al., 2012; SZABÓ et al., 2013b). The role of birds as host for this species is unclear. Some records do exist in Brazil (OGRZEWALSKA et al., 2009a; LUZ et al., 2012; PACHECO et al., 2012; RAMOS et al., 2015), Paraguay (OGRZEWALSKA et al., 2013), Argentina (FLORES et al., 2014), Panama (MURGAS et al., 2013), Costa Rica (OGRZEWALSKA et al., 2015); however, in areas of coastal rainforest of the São Paulo state, where $A$. ovale commonly parasitizes domestics dogs, wild birds seem not to be important for immature stages (OGRZEWALSKA, not published). Adults of $A$. ovale are the main vectors of Rickettsia parkeri-like strain responsible for a milder febrile human disease (SABATINI et al., 2010; SZABÓ et al., 2013a, b).

Amblyomma pacae Aragão, 1911 is a Neotropical tick whose usual hosts for adult and nymphs are Rodentia (Cuniculidae) (LABRUNA et al., 2005c; GUGLIELMONE et al., 2014). Records of human parasitism occur (GUGLIELMONE et al., 2014). Only one record exists of parasitism of birds Cariama cristata (Linnaeus, 1766) by larvae and nymphs; however, birds were maintained in captivity (TEIXEIRA et al., 2008).

\section{Amblyomma parkeri Fonseca and Aragão, 1952}

is a rare species, currently considered endemic to southeastern and southern Brazil. Amblyomma parkeri and A. longirostre are morphologically and ecologically closely related species. Their adult stages are commonly associated with porcupines from the family Erethizontidae (Rodentia) (LABRUNA et al., 2009; MARTINS et al., 2013). Immature stages were found on monkey Alouatta guariba Humboldt, 1812 (MARTINS et al., 2010, 2013), on D. albiventris (SPONCHIADO et al., 2015), Didelphis marsupialis Linnaeus, 1758 (WITTER et al., 2016), on porcupines (Erethizontidae) (GUGLIELMONE et al., 2014) and on birds in the Atlantic Forest region (OGRZEWALSKA et al., 2008, 2011a, 2012a; PACHECO et al., 2012). Additionally, Pacheco et al. (2012) found two and Ogrzewalska et al. (2012a) seven larvae of $A$. parkeri collected from wild birds infected with Rickettsia sp. ApPR, genotype of $R$. parkeri (Table 1). One record of parasitism of nymph on humans exists (MARTINS et al., 2013).

Amblyomma parvum Aragão, 1908 is a Neotropical species. There are records of $A$. parvum in the Amazon, Cerrado and Pantanal biomes in Brazil (MULLINS et al., 2004; SZABÓ et al., 2007a; CANÇADO et al., 2008; SARAIVA et al., 2012). Adult stages are frequently associated with a wide variety of wild and domestic mammals (LABRUNA et al., 2005b; NAVA et al., 2006, 2008b; SZABÓ et al., 2007a; MARTINS et al., 2011). Records exist of human parasitism (GUGLIELMONE et al., 2006). Despite the fact that immature stages seem to prefer small mammals (NAVA et al., 2006; HORTA et al., 2011; SARAIVA et al., 2012), birds also seem to take part in the life cycle for this tick in dry areas of the Cerrado and Caatinga biomes (LUZ et al., 2012; LUGARINI et al., 2015) and Chaco biome in Argentina (NAVA et al., 2006, 2008b). Parasitism of captive bird Rhea americana (Linnaeus, 1758) by adults was also reported (TEIXEIRA et al., 2008). Lugarini et al. (2015) found 'Canditatus Rickettsia andenae' in A. parvum collected from birds in Caatinga, northeastern Brazil.

Amblyomma triste Koch, 1844 is distributed from south of United States to Argentina. It is a 
member of the 'Amblyomma maculatum group' which also include Amblyomma maculatum Koch, 1844 and Amblyomma tigrinum Koch, 1844 (GUGLIELMONE et al., 2014). Ecological studies of A. triste in Brazil and Uruguay indicated that this tick species is strongly associated with wetlands and environments prone to flooding and the deer Blastocerus dichotomus Illiger, 1815 has been pointed out as one of the main hosts for the adults of A. triste. However, other mammals such as domestic and wild carnivores, cattle, goat, horse were also recorded as hosts for A. triste adults (LABRUNA et al., 2003; SZABÓ et al., 2003, 2007b; VENZAL et al., 2008; MARTINS et al., 2011; NAVA et al., 2011). Larvae and nymphs of $A$. triste are common parasites of small rodents (LABRUNA et al., 2003; VENZAL et al., 2008; NAVA et al., 2011) and birds in Argentina (NAVA et al., 2011; FLORES et al., 2014) and in United States (MERTINS et al., 2010). In Brazil, there are only two records of parasitism of wild birds from flooded lowland grassland in the São Paulo State (SILVEIRA et al., 2015) and Mato Grosso State (RAMOS et al., 2015). This tick is of public health relevance as its species is frequently found biting humans (GUGLIELMONE et al., 2006) and involved in epidemiology of spotted fever caused by $R$. parkeri in Uruguay (VENZAL et al., 2004b; PACHECO et al., 2006; VENZAL et al., 2012), Argentina (NAVA et al., 2008a) and possibly in Brazil (SILVEIRA et al., 2007; MELO et al., 2015).

Amblyomma varium Koch, 1844. This tick is widely distributed from southern Central America to Argentina (GUGLIELMONE et al., 2014). It is known in Brazil as the "sloth's giant" because during the adult stage, the tick presents a high host specificity and is found almost exclusively on the sloths from the families Bradypodidae and Megalonychidae (MARQUES et al., 2002; GUGLIELMONE et al., 2014). The hosts of immature stages are only limited to rare records on wild birds in Brazil (LUGARINI et al., 2015), Peru (OGRZEWALSKA et al., 2012b), and Costa Rica (OGRZEWALSKA et al., 2015). Two nymphs of $A$. varium collected from Elaenia flavogaster Thunberg, 1822 and from Thamnophilus sp. (Passeriformes, Thamnophilidae), Prado, Bahia, were infected with 'Ca. Rickettsia amblyommii', identical with strain AL (data not published, Table 1). Lugarini et al. (2015) reported larvae of A. varium collected from the clothes and skin of the field team in costal Atlantic forest in Paraíba State, Brazil infected 'Ca. Rickettsia amblyommii'-like agent. In Peru, two larvae collected from dove Leptotila rufaxilla Richard and Bernard, 1792 were found infected with R. bellii (OGRZEWALSKA et al., 2012b).

Amblyomma sp. haplotype Nazare. Twelve Amblyomma sp. larvae were collected from forest Passeriformes birds, in the region of Nazaré Paulista, São Paulo State, Brazil and their DNA sequence of a fragment of the mitochondrial 16S rDNA was most similar $(90 \%)$ to $A$. parkeri and $(88 \%)$ to $A$. longirostre. Three larvae have been found infected with $R$. parkeri-like agent (OGRZEWALSKA et al., 2012a).

\section{Haemaphysalis}

Haemaphysalis juxtakochi Cooley, 1946. This tick occurs in several different Nearctic and Neotropical ecoregions. Usual hosts for adult ticks are Artiodactyla: Cervidae but it is also found on other large mammals (GUGLIELMONE et al., 2014). Few records exist of bird parasitism in Brazil (ARZUA et al., 2005; OGRZEWALSKA et al., 2010), Uruguay (VENZAL et al., 2005), and in Argentina (BELDOMENICO et al., 2003; FLORES et al., 2014). Rickettsia rhipicephali was isolated from adult ticks in Rondônia (LABRUNA et al., 2005c), São Paulo (LABRUNA et al., 2007b) and R. bellii from São Paulo State (LABRUNA et al., 2007b).

Haemaphysalis leporispalustris Packard, 1869 has wide distribution across the American continent, from Alaska to Argentina (GUGLIELMONE et al., 2014). Usual hosts for larvae, nymphs and adult ticks are wild rabbits (Lagomorpha: Leporidae), and birds 
appear to be alternative hosts for the immature stages in some areas (STAFFORD et al., 1995; BELDOMENICO et al., 2003; FLORES et al., 2014). A few records in Brazil on parasitism on birds are from the São Paulo, Paraná, Rio de Janeiro and Minas Gerais states (ARZUA et al., 2005; OGRZEWALSKA et al., 2012a; ZERINGÓTA et al., 2016). Although $H$. leporispalustris is not a classical human-biting tick, previous studies suggested that this tick is important in the enzootic maintenance of $R$. rickettsii in nature (HUN et al., 2008).

\section{Ixodes}

Ixodes auritulus Neumann, 1904 is a bird tick found in the Australian, Ethiopian, Nearctic and Neotropical zoogeographic regions with records in Ecuador, Chile, Peru, Costa Rica, Argentina, Colombia, Guatemala, Uruguay and Brazil (GUGLIELMONE et al., 2014). It was suggested that I. auritulus is a catchall name for a tick species group (GONZÁLEZ-ACUNA et al., 2005). In Brazil, the only records are from the states of Paraná, São Paulo and Rio de Janeiro (ARZUA; BARROS-BATTESTI, 1999; ARZUA et al., 1994, 2003, 2005; GONZÁLEZACUNA et al., 2005). Males of I. auritulus are not commonly found on hosts. No Rickettsia was found. Although I. auritulus does not bite humans, this tick species helps to maintain Borrelia burgdorferi in the enzootic transmission cycles in Canada (MORSHED et al., 2005; SCOTT et al., 2015).

Ixodes paranaensis Barros-Battesti, Arzua, Pichorim and Keirans, 2003. This species was found for the first time in a colony of swifts Streptoprocne biscutata Sclater, 1866 (Apodiformes, Apodidae), in caves in Paraná State, southern Brazil (BARROSBATTESTI et al., 2003), and only two other records exist, both from the State of Minas Gerais, southeastern Brazil; the first one in a cave and breeding site for S. biscutata (DANTAS-TORRES et al., 2009b) and on swifts S. zonaris and Cypseloides senex Temminck, 1826 caught at waterfalls in Minas Gerais State (TOLESANO-PASCOLI et al., 2014).
This tick species is probably nidicolous, meaning with its entire life cycle occurs in the nest with the bird as host (BARROS-BATTESTI et al., 2003). No records of pathogen infection exist.

Ixodes sp. One, not identified nymph found on Trichothraupis melanops Vieillot, 1818 (Passeriformes, Thraupidae) in the São Paulo State (OGRZEWALSKA et al., 2012a).

\section{Rhipicephalus}

Rhipicephalus sanguineus Latreille, 1806. In the Neotropical region, $R$. sanguineus has as its primary host dogs from urban or rural environments, but also wild carnivores associated with domestic dogs (LABRUNA et al., 2005a, b). However, recent studies based on phylogenetic analysis and laboratory crosses show the presence of at least two species under the taxon $R$. sanguineus in the New World (MORAESFILHO et al., 2011). Sporadic records of parasitism of birds exist, but are unexpected and are rather related with habits of synanthropic birds sharing the environment with domestic dogs (DIOGO et al., 2003; SZABÓ et al., 2008; LUZ et al., 2012; LUGARINI et al., 2015). Worldwide ticks from $R$. sanguineus complex have been linked to tick-borne diseases such as spotted and boutonneuse fever and ehrlichiosis in humans, and canine babesiosis and ehrlichiosis (reviewed by GRAY et al., 2013); however, further work is required to clearly define the taxonomic status of $R$. sanguineus (NAVA et al., 2015).

\section{Birds as part of the rickettsial life cycle}

\section{Rickettsia}

Rickettsiae are rod-shaped, small $(0.3$ to $0.5 \mu \mathrm{m}$ by 0.8 to $2.0 \mu \mathrm{m})$, gram-negative, non-sporeforming bacteria. They are obligate intracellular bacteria, which means they can only reproduce within animal cells (RAOULT; ROUX, 1997). The members of the Rickettsiaceae family are maintained in nature through complex cycles involving reservoir in 
mammals and arthropod vectors such as ticks, mites and lice (RAOULT; ROUX, 1997). Except for $R$. prowazekii, humans are only accidental hosts for rickettsiae and usually get infected through bites or feces of infected arthropods. Some of these diseases are benign for humans, while others may be fatal. Currently, 26 species with validated and published names within the genus Rickettsia exist. However, some species are divided into subspecies and more than 70 strains remain unidentified or incompletely described pathogens. Moreover, new species, or stains are discovered each year (reviewed by PAROLA et al., 2013). Until 2003, R. rickettsii was the only rickettsia that was reported infecting ticks in Brazil. During the last 12 years, there has been an increasing number of tick-associated rickettsiae in this country, with reports of various strains of $R$. parkeri, $R$. rhipicephali, $R$. monteiroi, $R$. massiliae, R. bellii, 'Ca. R. amblyommii' and 'Ca. Rickettsia andeanae' infecting South American ticks (Reviewed by LABRUNA, 2009; NIERI-BASTOS et al., 2014).

It is noteworthy how birds play an import role as host to ticks. On the other hand, many questions still remain unsolved as to the role of avian hosts as reservoirs or amplifiers of Rickettsia. Randolph (1998) describes the important differences between ticks and insects with respect to competence of being a reservoir and vector of pathogens. In fact, when compared to haematophagus insects, hard ticks show a longer lifespan and fewer blood meals. In order to be successfully transmitted by ticks, a pathogen organism must use two main strategies: First, use a vertebrate animal as a reservoir in order to be accessed by ticks and, second, successfully use the tick female transovarian route combined with using vertebrate hosts as amplifiers in order to spread horizontally on tick population. Cooksey et al. (1990) describes that the $R$. rickettsii life cycle relies on the second strategy; therefore, at least one rickettsial amplifier host must be identified among the most sui tick hosts on determined localization, otherwise the bacteria would disappear from a ticks' population.
Moreover, Labruna (2009) postulates that the $R$. rickettsii amplifier hosts must fulfill five requirements: 1) It has to be abundant; 2) It has to be a major host for the tick vector; 3 ) It has to be sui to $R$. rickettsia infection; 4) Once infected, it must develop a rickettsemia period and be a source of infection to ticks; 5) It has to be a prolific species. In fact, birds suit at least three of the five requirements. Birds are abundant, prolific and major hosts for several tick species. Nevertheless, very few studies discuss the capacity of birds to be infected and to be a course of tick infection. Several studies were conducted in the United States in the mid-twentieth century to discover Rickettsia animal reservoirs, before the concept of amplifier was established. Vest et al. (1965) were not able to find rickettsial agents in tissue samples of 326 wild birds tested in Unites States. Although the spotted fever group antibodies were detected in sera of two birds, the authors suggest that these antibody titers are rather due to nonspecific factors in the sera, rather than indicative of rickettsial infection. Experimentally, Lundgren et al. (1966) inoculated $R$. rickettsii in different species of birds (chickens, pigeons, pheasants, sparrow hawks, redtailed hawks, ravens, magpies, and a marsh hawk); only pigeons showed antibody titers, but all them presented rickettsemia that was weak and transient in some species. However, the capacity of the birds being an infection source was not accessed.

More recently, Moraru et al. (2013) tested laboratory infected cotton rats and quail as amplifier hosts for $R$. parkeri. While viable $R$. parkeri was reisolated from blood, skin and spleen tissues of the cotton rats, none was found on quails. This experiment shows that in the same conditions of infection, R. parkeri was able to amplify in cotton-rats but not in quail. Maciel et al. (2013) tested 300 chickens that were maintained freely on an endemic area for rickettsial infected ticks, and only $1.33 \%$ of the animals yielded seropositive outcome.

Only a few studies so far identified a rickettsial agent in wild sampled birds. et al. (2010) recorded 
Rickettsia infection in blood samples of wild Passeriformes birds Periparus ater (Linnaeus, 1758), Parus major Linnaeus, 1758, Cyanistes caeruleus (Linnaeus, 1758) and Chloris chloris (Linnaeus, 1758) that sampled from Slovakia, Austria and the Czech Republic. Ioannou et al. (2009) sampled 557 migratory birds in Cyprus and after processing the samples in 131 pools, found 3\% positive in PCR for genus Rickettsia. Elfving et al. (2010) conducted a field study collecting birds in migratory route in Northern Europe, and found that the occurrence of infected ticks does not support the thesis that birds play a role as reservoir or amplifier host for rickettsial agents. Hornok et al. (2014) sampled 128 migratory birds in central Europe and found $4.7 \%$ of them PCR positive for Rickettsia helvetica. This finding points out that birds can be infected by $R$. helvetica and furthermore, infection does not prevent birds from migrating as much as non-infected birds. In the United States, Mukherjee et al. (2014) found birds naturally infected with rickettsial agents, but no correlation with the pathogens found on the ticks feeding on the same birds, supporting the thesis that the birds may not be a source of tick infection. In another study, Erwin et al. (2016) found Rickettsia felis in one among 55 Caracara cheriway (Jacquin, 1784) in Florida, USA, and concluded that the low prevalence of infections suggests the populations of $C$. cheriway likely do not function as an ecological reservoir. Berthová et al. (2016) found Rickettsia spp. in $8.9 \%$ and Rickettsia helvetica in $4.2 \%$ of 336 Passeriformes bird blood samples in Slovakia and suggested that further studies are necessary to define the role of birds in the circulation of rickettsiae in natural foci. In Brazil, there are unpublished results about possible infection of birds with Rickettsia; however, some studies show that ticks collected from wild birds are infected with some rickettsial agents.

\section{Rickettsia species found in ticks parasitizing birds in Brazil}

Rickettsia bellii is considered the most common Rickettsia in various tick species from the New World (reviewed by LABRUNA, 2009; BARBIERI et al., 2012). In Brazil, $R$. bellii has been isolated by Pinter and Labruna (2006) from A. aureolatum tick collected from a domestic dog in the São Paulo State. Later, this bacterium has been found infecting $A$. aureolatum ticks in other areas (SABATINI et al., 2010; OGRZEWALSKA et al., 2012a), A. cajennense (DE BARROS-LOPES et al., 2014), A. dubitatum (LABRUNA et al., 2004b; HORTA et al., 2007; PACHECO et al., 2009; BRITES-NETO et al., 2013; MOURA-MARTINIANO et al., 2015), Amblyomma incisum Neumann, 1906 (PACHECO et al., 2008; SABATINI et al., 2010), A. ovale (LABRUNA et al., 2004a; PACHECO et al., 2008; SABATINI et al., 2010; SZABÓ et al., 2013b), A. longirostre (MCINTOSH et al., 2015), Amblyomma scalpturatum Neumann, 1906, Amblyomma oblongoguttatum Koch, 1844, Amblyomma rotundatum Koch, 1844, and A. humerale (LABRUNA et al., 2004a), H. juxtakochi (LABRUNA et al., 2007b), Ixodes loricatus Neumann, 1899 (HORTA et al., 2006, 2007; OGRZEWALSKA et al., 2012a). Finally, R. bellii has been also found in immature ticks collected from wild birds: $A$. auricularium and $A$. nodosum (Table 1). Currently, $R$. bellii is considered non-pathogenic to humans (LABRUNA, 2009) and other animals (HORTA et al., 2007; PINTER et al., 2008).

'Candidatus Rickettsia andenae' is a spotted fever group agent infecting found infecting adults of A. parvum in Argentina (PACHECO et al., 2007), Brazil (NIERI-BASTOS et al., 2014), A. maculatum in Unites States (PADDOCK et al., 2010; FORNADEL et al., 2011; JIANG et al., 2012; FERRARI et al., 2013; NADOLNY et al., 2014) and Peru (BLAIR et al., 2004; JIANG et al., 2005; FLORES-MENDOZA et al., 2013), Amblyomma pseudoconcolor Aragão, 1908 in Argentina (TOMASSONE et al., 2010a), A. triste in Chile (ABARCA et al., 2012), A. sculptum in Brazil 
(WITTER et al., 2016), R. sanguineus (FLORESMENDOZA et al., 2013), and Ixodes boliviensis Neumann, 1904 (JIANG et al., 2005) in Peru. Nymphs of A. parvum collected from wild birds of were found infected with this Rickettsia in Paraguay (OGRZEWALSKA et al., 2014), and in Brazil (LUGARINI et al., 2015) (Table 1). The role of " $\mathrm{Ca}$. Rickettsia andeanae" as a human pathogen is unknown.

'Candidatus Rickettsia amblyommii' is an incompletely characterized alphaproteobacterium in the spotted fever group (SFG) of organisms. This bacterium seems to have a wide distribution and has been found infecting various species of ticks across various countries in the Americas: Unites States (STROMDAHL et al., 2008; JIANG et al., 2010; MONCAYO et al., 2010; TROUT et al., 2010; WILLIAMSON et al., 2010), Honduras (NOVAKOVA et al., 2015), Costa Rica (HUN et al., 2011; OGRZEWALSKA et al., 2015), Panama (BERMUDEZ et al., 2011), French Guyana (PAROLA et al., 2007) and Argentina (LABRUNA et al., 2007c). In Brazil, this species was isolated in 2004 for the first time from ticks found in Rondônia State, Western Amazon. The strain isolated form adult male $A$. longirostre collected from a porcupine Coendou prehensilis Linnaeus, 1758, was designated as the strain Aranha (LABRUNA et al., 2004c). Later, closely related genotypes were found also in A. auricularium (SARAIVA et al., 2013), A. cajennense (LABRUNA et al., 2004a; DE BARROS-LOPES et al., 2014; WITTER et al., 2016), A. coelebs (LABRUNA et al., 2004b; SILVEIRA et al., 2015; WITTER et al., 2016) and $A$. longirostre (MEDEIROS et al., 2011; MCINTOSH et al., 2015). In 2006 Ogrzewalska et al. (2008) isolated "Ca. Rickettsia amblyommii" or closely related bacteria denominated strain AL from and adult ticks obtained from engorged nymph collected from Conopophaga lineata (Wied, 1831) (Passeriformes, Conopophagidae), State of São Paulo. Since then, " $\mathrm{Ca}$. Rickettsia amblyommii" have been found frequently infecting immature ticks $A$. longirostre collected on birds (Table 1). Recently, immature A. auricularim A. geay, A. nodosum, A. varium, also collected from birds have been found infected with this or closely related bacteria (Table 1). The pathogenicity for humans of 'Ca. Rickettsia amblyommii' remains unknown; however, there was serological evidence of exposure of humans and canines to this agent in the USA and in the Brazilian western Amazon (LABRUNA et al., 2007d), and recently it was associated in USA with a rash in humans (BILLETER et al., 2007). It was also proposed that some of the rickettsiosis cases reported as Rocky Mountain spotted fever in the USA may have been caused by "Ca. Rickettsia amblyommii" instead of $R$. rickettsii (APPERSON et al., 2008).

\section{Rickettsia parkeri and Rickettsia parkeri-like strains}

Rickettsia parkeri agent is responsible for spotted fever cases in humans in the United States where it is transmitted by Amblyomma maculatum Koch, 1844 (PADDOCK et al., 2004, 2008; WHITMAN et al., 2007; FORNADEL et al., 2011). This pathogen was also detected in A. maculatum in Peru (FLORESMANDONZA et al., 2013), A. triste in Uruguay (VENZAL et al., 2004a, 2012; PACHECO et al., 2006; CONTI-DÍAZ et al., 2009), Argentina (NAVA et al., 2008a) and Brazil (SILVEIRA et al., 2007) and in A. tigrinum in Bolivia (TOMASSONE et al., 2010b). Closely related with $R$. parkeri, strain denominated Rickettsia sp. Atlantic Rainforest was also found in Brazilian populations of $A$. ovale and A. aureolatum ticks (SABATINI et al., 2010; MEDEIROS et al., 2011; BARIBIERI et al., 2014; WITTER et al., 2016) and was recently proven to cause a milder version of Brazilian spotted fever caused by $R$. rickettsii (SPOLIDORIO et al., 2010; SILVA et al., 2011). Moreover, in Brazil, various other strains of $R$. parkeri-like have been found, including ticks collected on wild birds; in $A$. nodosum: Rickettsia sp strain NOD (OGRZEWALSKA et al., 2009b; WITTER et al., 
2016), strain PNCG (RAMOS et al., 2015), strain Paraiba (LUGARINI et al., 2015), in A. longirostre: strain ApPR (PACHECO et al., 2012), and in $A$. calcaratum $R$. parkeri-like (OGRZEWALSKA et al., 2013) (Table 1). The role of these bird ticks in the cycle of Rickettsia and its possible impact on public health remains unknown.

\section{Final Considerations}

Although information about the role of wild birds in the life cycle of South American ticks has increased in recent years, little is still known. Most of the available studies concern the role of birds as possible host in the life cycle of ticks, and it seem that for at least six species such as $A$. calcaratum, A. longirostre A. nodosum, I. auritulus and I. paranaensis, birds are essential host for immatures stages. For others, such as A. parvum, A. triste, $H$. juxtakochi, $H$. leporispalustris, birds are important, but not essential and rather alternative hosts. For other tick species $A$. aureolatum, A. auricularium, A. geayi, A. humerale, A. ovale, A. parkeri, A. varium, O. mimon, birds are possibly important hosts; however, data are very limited and require further investigations. And finally, for A. brasiliense, A. sculptum, A. coelebs, $A$. dissimile, A. naponense, A. pacae and R. sanguineus, birds seem rather accidental hosts.

Bird tick fauna is the best known from the region of Atlantic Forest and Cerrado, and there is a lack of knowledge about bird parasitism in other Brazilian biomes. It is important to highlight that even the available data are mainly obtained by capturing birds by mist nests; thus, data are not completely representative. Mist nets were invented over 300 years ago in Japan for capturing birds for food (SPENCER,
1972) and remain the most commonly used method for capturing birds for research. However, netting is usually used for sampling small to medium-sized wild birds such as passerines and shorebirds and is known to under-sample or completely miss birds living in canopy stratum (e.g. parrots, raptors, toucans) and large terrestrial birds (e.g. tinamous, curassows guans) (WANG; FINCH, 2002). For capturing these groups, other methods such as baited traps are indicated (BUB, 1991). Thus, caution should always be taken when making conclusions based only on this selective data. The important group of midsize to large terrestrial birds are not accessed often in parasitology studies. It is expected that terrestrial birds are exposed to larger burden of subadult ticks, and because of the closer and constant contact, it would be expected that most of the records of ticks on birds would come from this group. However, more studies with this group of birds must be taken in order to fill the knowledge gaps.

It seems very unlikely that birds play a major role as amplifier hosts for rickettsial agents, even though this hypothesis has yet to be more extensively tested. On the other hand, birds may be an important source of spatial dispersion of rickettsial agents alongside the tick population itself; however, the dynamic of dispersion of tick by birds is not well known in South America. Although most Brazilian birds are resident, not migratory species (CBRO, 2014), it is likely that birds are essential in spreading ticks and pathogens within ecosystems they habit. Further studies must be carried out in order to quantifiably measure this hypothesis and interaction among birds, ticks and rickettsial agents as this is an import concern for public health, and continues to be an open field for research. 


\section{Some examples of parasitism of wild birds by Amblyomma ticks in Atlantic Forest region, São Paulo State, Brazil}

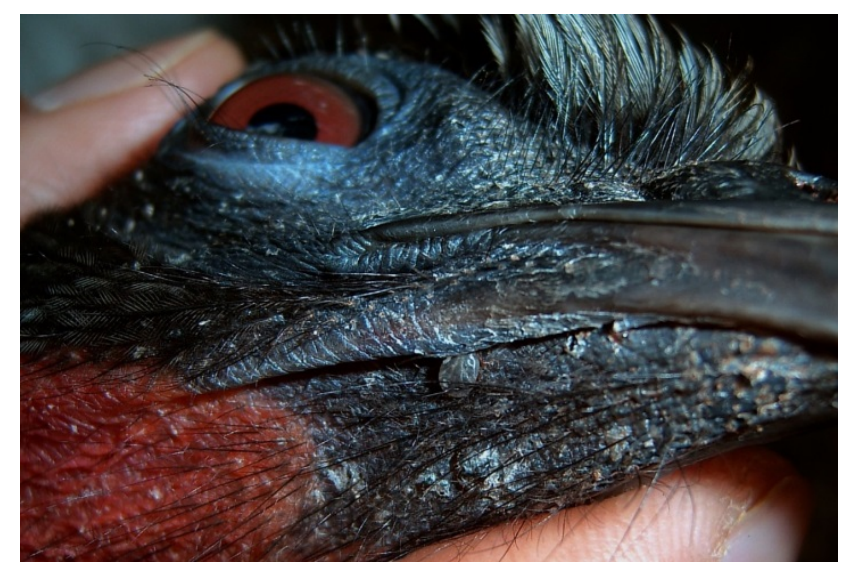

Figure 1 - Nymph of Amblyomma sculptum on Penelope superciliaris (Galliformes, Cracidae)

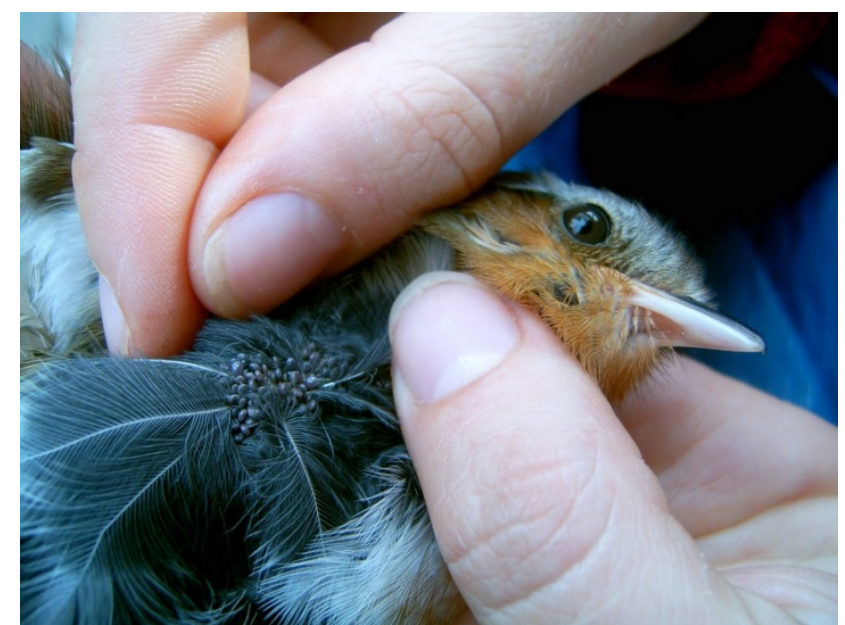

Figure 2 - More than 500 larvae of Amblyomma nodosum on Conopophaga lineata (Passeriformes, Conopophagidae)

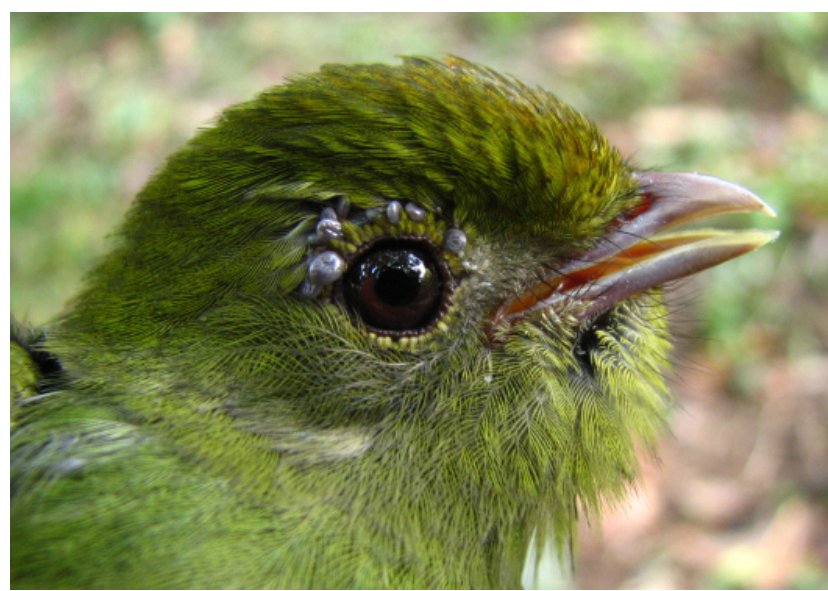

Figure 3 - Larvae of Amblyomma longirostre on Schiffornis virescens (Passeriformes, Tityridae)

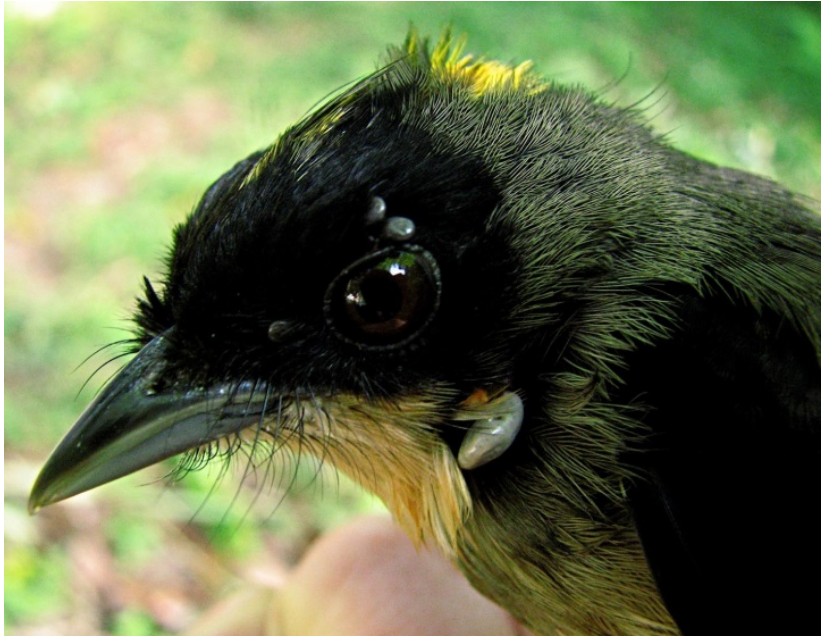

Figure 4 - Larvae (above the eye) of Amblyomma spp and nymph (neck) of Amblyomma longirostre on Lanio (Trichothraupis) melanops (Passeriformes, Thraupidae)

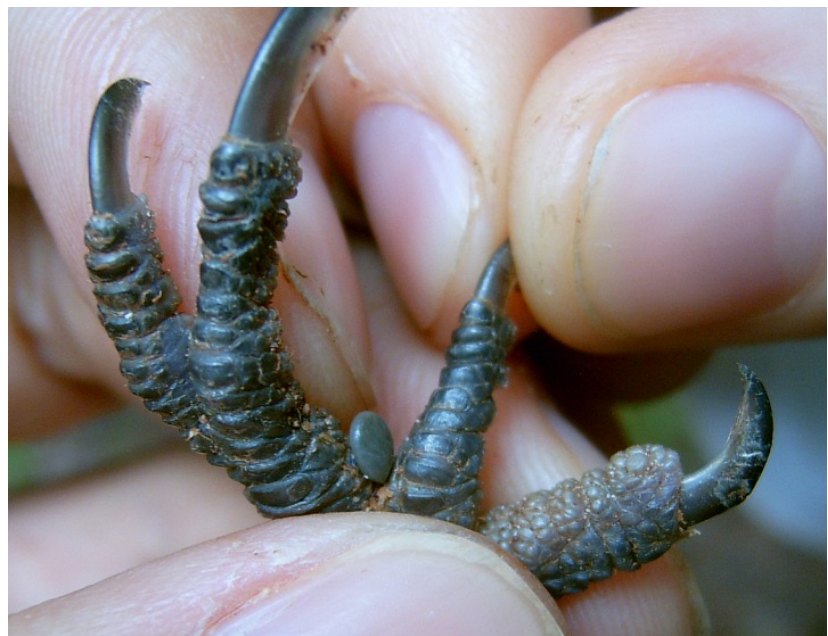

Figure 5 - Nymph of Amblyomma coelebs on Baryphthengus ruficapillus (Coraciiformes, Momotidae)

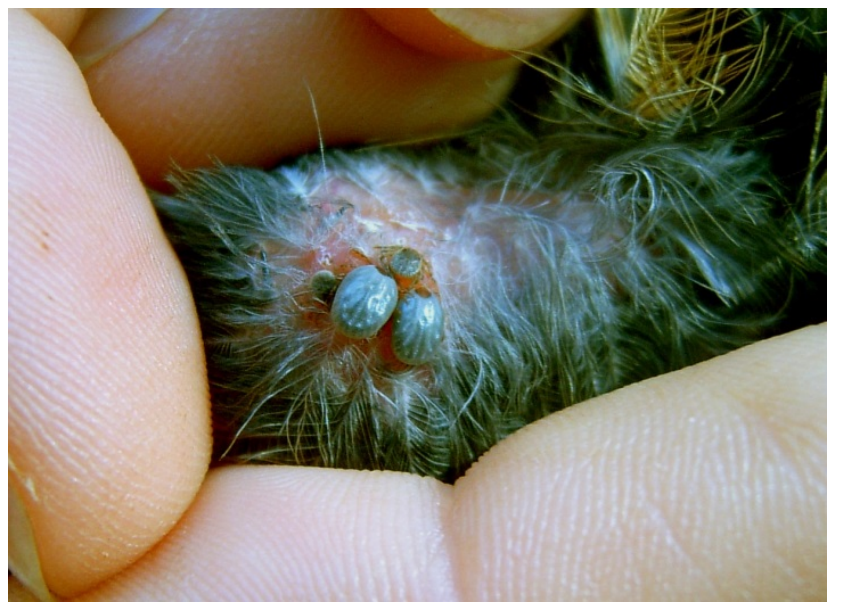

Figure 6 - Nymphs of Amblyomma nodosum on the neck of Thamnophilus pelzelni (Passeriformes, Thamnphilidae) 


\section{References}

ABARCA, K.; LÓPEZ, J.; ACOSTA-JAMETT, G.; LEPE, P.; SOARES, J. F.; LABRUNA, M. B. A third Amblyomma species and the first tick-borne Rickettsia in Chile. Journal of Medical Entomology, v. 49, n. 1, p. 219-222, 2012. doi: http://dx.doi.org/10.1603/ME11147.

ALEKSEEV, A. N.; DUBININA, H. V.; SEMENOV, A. V.; BOLSHAKOV, C. V. Evidence of ehrlichiosis agents found in ticks (Acari: Ixodidae) collected from migratory birds. Journal of Medical Entomology, v. 38, n. 4, p. 471-474, 2001. doi: http://dx.doi.org/ 10.1603/0022-2585-38.4.471.

ALMEIDA, R. F. C.; GARCIA, M. V.; CUNHA, R. C.; MATIAS, J.; LABRUNA, M. B.; ANDREOTTI, R. The first report of Rickettsia spp. in Amblyomma nodosum in the State of Mato Grosso do Sul, Brazil. Ticks and Tick-borne Diseases, v. 4, n. 1-2, p. 156-159, 2012. doi: http://dx.doi.org/10.1016/j.ttbdis.2012.08.002.

ANDERSON, J. F.; JOHNSON, R. C.; MAGNARELLI, L. A.; HYDE, F. W. Involvement of birds in the epidemiology of the Lyme disease agent Borrelia burgdorferi. Infection and Immunity, v. 51, n. 2, p. 394-396, 1986.

APPERSON, C. S.; ENGBER, B.; NICHOLSON, W. L.; MEAD, D. G.; ENGEL, J.; YABSLEY, M. J.; DAIL, K.; JOHNSON, J.; WATSON, D.W. Tick-borne diseases in North Carolina: is "Rickettsia amblyommii" a possible cause of rickettsiosis reported as rocky mountain spotted fever? Vector-Borne and Zoonotic Diseases, v. 8, n. 5, p. 597-606, 2008. doi: http://dx.doi.org/10.1089/vbz.2007.0271.

ARAGÃO, H. B. Ixodidas brasileiros e de alguns paizes limitrophes. Memórias do Instituto Oswaldo Cruz, v. 31, n. 4, p. 759-844, 1936. doi: http://dx.doi.org/10.1590/S007402761936000400004 .

ARAUJO, J.; AZEVEDO JÚNIOR, S. M.; GAIDET, N.; HURTADO, R. F.; WALKER, D.; THOMAZELLI, L. M.; OMETTO, T.; SEIXAS, M. M. M.; RODRIGUES, R.; GALINDO, D. B.; SILVA, A. C.; RODRIGUES, A. M. M.; BOMFIM, L. L.; MOTA, M. A.; LARRAZÁBAL, M. E.; BRANCO, J. O.; SERAFINI, P.; NETO, I. S.; FRANKS, J.; WEBBY, R. J.; WEBSTER, R. G.; DURIGON, E. L. Avian Influenza Virus (H11N9) in migratory shorebirds wintering in the Amazon Region, Brazil. Plos One, v. 9, n. 10, p. e110141, 2014. doi: http//dx.doiorg/10.1371/journal.pone.0110141.

ARZUA, M.; BARROS, D. M.; LINARDI, P. M.; BOTELHO, J. R. Noteworthy records of Ixodes auritulus
Neumann, 1904 (Acari, Ixodida) on birds from Paraná, southern Brazil. Memórias do Instituto Oswaldo Cruz, v. 89, n. 1, p. 129, 1994. doi: http://dx.doi.org/10.1590/S007402761994000100026.

ARZUA, M.; BARROS-BATTESTI, D. M. Parasitism of Ixodes (Multidentatus) auritulus Neumann (Acari: Ixodidae) on birds from the city of Curitiba, state of Paraná, southern Brazil. Memórias do Instituto Oswaldo Cruz, v. 94, n. 5, p. 597-603, 1999. doi: http://dx.doiorg/10.1590/S0074 02761999000500006 .

ARZUA, M.; ONOFRIO, V. C.; BARROS-BATTESTI, D. M. Catalogue of the tick collection (Acari, Ixodida) of the Museu de História Natural Capão da Imbuia, Curitiba, Paraná, Brazil. Revista Brasileira de Zoologia, v. 22, n. 3, p. 623-632, 2005. doi: http://dx.doi.org/10.1590/S010181752005000300015 .

ARZUA, M.; SILVA, M. A. N.; FAMADAS, K. M.; BEATI, L.; BARROS-BATTESTI, D. M. Amblyomma aureolatum and Ixodes auritulus (Acari: Ixodidae) on birds in southern Brazil, with notes on their ecology. Experimental and Applied Acarology, v. 31, n. 3, p. 283-296, 2003. doi: http://dx.doi.org/10.1023/B:APPA.0000010381.24903.1c.

BARBIERI, A. R. M.; FILHO, J. M.; NIERI-BASTOS.; F. A.; SOUZA JR., J. C.; SZABÓ, M. P. J.; LABRUNA, M. B. Epidemiology of Rickettsia sp. strain Atlantic rainforest in a spotted fever-endemic area of southern Brazil. Ticks and Tick-borne Diseases, v. 5, n. 6, p. 848-853, 2014. doi: http://dx.doi.org/10.1016/j.ttbdis.2014.07.010.

BARBIERI, A. R. M.; ROMERO, L.; LABRUNA, M. B. Rickettsia bellii infecting Amblyomma sabanerae ticks in El Salvador. Pathogens and Global Health, v. 106, n. 3, p. 188-189, 2012. doi: http://dx.doiorg/10.1179/2047773212Y.0000000022.

BARROS-BATTESTI, D. M.; ARZUA, M.; BECHARA, G. $H$. Carrapatos de importância médico-veterinária da Região Neotropical: Um guia ilustrado para identificação de espécies. São Paulo: Vox/ICTTD-3/Butantan, 2006. 223p.

BARROS-BATTESTI, D. M.; ARZUA, M.; PICHORIM, M.; KEIRANS, J. E. Ixodes (Multidentatus) paranaensis n. sp. (Acari: Ixodidae) a parasite of Streptoprocne biscutata (Sclater 1865) (Apodiformes: Apodidae) birds in Brazil. Memórias do Instituto Oswaldo Cruz, v. 98, n. 1, p. 93102, 2003. doi: http//dx.doi.org/10.1590/S0074-02762003000100013. BARROS-BATTESTI, D. M.; LANDULFO, G. A.; ONOFRIO, V. C.; FACCINI, J. L. H.; MARCILI, A.; NIERI- 
BASTOS, F. A.; VENZAL, J. M.; LABRUNA, M. B. Carios mimon (Acari: Argasidae): description of adults and redescription of larva. Experimental and Applied Acarology, v. 54, n. 1, 193-104, 2011. doi: http://dx.doi.org/10.1007/s10493-010-9416-2.

BARROS-BATTESTI, D. M.; LANDULFO, G. A.; LUZ, H. R.; MARCILI, A.; ONOFRIO, V. C.; FAMADAS, K. M. Ornithodoros faccinii n. sp. (Acari: Ixodida: Argasidae) parasitizing the frog Thoropa miliaris (Amphibia: Anura: Cycloramphidae) in Brazil. Parasites and Vectors, v. 8, p. 268, 2015. doi: http://dx.doi.org/10.1186/s13071-015-0877-3.

BEATI, L.; KEIRANS, J. E. Analysis of the systematic relationships among ticks of the genera Rhipicephalus and Boophilus (Acari: Ixodidae) based on mitochondrial $12 \mathrm{~S}$ ribosomal DNA gene sequences and morphological characters. Journal of Parasitology, v. 87, n. 1, p. 32-48, 2001. doi: http://dx.doi.org/10.1645/00223395(2001)087[0032:AOTSRA]2.0.CO;2.

BEATI, L.; NAVA, S.; BURKMAN, E. J.; BARROSBATTESTI, D. M.; LABRUNA, M. B.; GUGLIELMONE, A. A.; CÁCERES, A. G.; GUZMÁN-CORNEJO, C. M.; LEÓN, R.; DURDEN, L. A.; FACCINI, J. L. H. Amblyomma cajennense (Fabricius, 1787) (Acari: Ixodidae), the cayenne tick: Phylogeography and evidence for allopatric speciation. BMC Evolutionary Biology, v. 13, p. 267, 2013. doi: http://dx.doi.org/10.1186/1471-2148-13-267.

BECHARA, G. H.; SZABO', M. P. J.; ALMEIDA FILHO, W. V.; BECHARA, J. N.; PEREIRA, R. J. G.; GARCIA, J. E.; PEREIRA, M. C. Ticks associated with Armadillo (Euphractus sexcinctus) and anteater (Myrmercophaga tridactyla) of Emas National Park, State of Goiás, Brazil. Annals of New York Academy of Science, v. 969, p. 290293, 2002. doi: http://dx.doi.org/10.1111/j.17496632.2002.tb04394.x.

BELDOMENICO, P. M.; BALDI, C. J.; ANTONIAZZI, L. R.; ORDUNA, G. M.; MASTROPAOLO, M. MACEDO, A. C.; RUIZ, M. F.; ORCELLET, V. M.; PERALTA, J. L.; VENZAL, J. M.; MANGOLD, A. J.; GUGLIELMONE, A. A. Ixodid ticks (Acari: Ixodidae) present at Parque Nacional El Rey, Argentina. Neotropical Entomology, v. 32, n. 2, p. 273-277, 2003. doi: http://dx.doi.org/10.1590/S1519566X2003000200012.

BERMÚDEZ, C. S. E.; ZALDÍVAR, A. Y.; SPOLIDORIO, M. G.; MORAES-FILHO, J.; MIRANDA, R. J.; CABALLERO, C. M.; MENDOZA, Y.; LABRUNA, M. B. Rickettsial infection in domestic mammals and their ectoparasites in El Valle de Antón, Coclé, Panamá.
Veterinary Parasitology, v. 177, n. 1-2, p. 134-138, 2011. doi: http://dx.doi.org/10.1016/j.vetpar.2010.11.020.

BERTHOVÁ, L.; SLOBODNIK, V.; SLOBODNIK, R.; OLEKSAK, M.; SEKEYOVA, Z.; SVITALKOVA, Z.; KAZIMIROVA, M.; SPITALSKA, E. The natural infection of birds and ticks feeding on birds with Rickettsia spp. and Coxiella burnetii in Slovakia. Experimental and Applied Acarology, v. 68, p. 299-314, 2016 doi: http://dx.doi.org/10.1007/s10493-015-9975-3.

BILLETER, S. A.; BLANTON, H. L.; LITTLE, S. E.; LEVY, M. G.; BREITSCHWERDT, E. B. Detection of Rickettsia amblyommii in association with a tick bite rash. VectorBorne and Zoonotic Diseases, v. 7, n. 4, p. 607-610, 2008. doi: http://dx.doi.org/10.1089/vbz.2007.0121.

BJÖERSDORFF, A.; BERGSTRÖM, S.; MASSUNG, R. F.; HAEMIG, P. D.; OLSEN, B. Ehrlichia-infected ticks on migrating birds. Emerging Infectious Diseases, v. 7, n. 5, p. 877-879, 2001. doi: http://dx.doi.org/10.3201/eid0705.017517.

BLAIR, P. J.; JIANG, J.; SCHOELER, G. B.; MORON, C.; ANAYA, E.; CESPEDES, M.; CRUZ, C.; FELICES,V.; GUEVARA, C.; MENDOZA, L.; VILLASECA, P.; SUMNER, J. W. RICHARDS, A. L.; OLSON, J. G. Characterization of spotted fever group rickettsiae in flea and tick specimens from northern Peru. Journal of Clinical Microbiology, v. 42, n. 11, p. 4961-4967, 2004. doi: http://dx.doi.org/10.1128/JCM.42.11.4961-4967.2004.

BRITES-NETO, J.; NIERI-BASTOS, F. A.; BRASIL, J.; DUARTE, K. M. R.; MARTINS, T. F.; VERISSIMO, C. J.; BARBIERI, A. R. M.; LABRUNA, M. B. Environmental infestation and rickettsial infection in ticks in an area endemic for Brazilian spotted fever. Revista Brasileira de Parasitologia Veterinária, v. 22, n. 3, p. 367-372, 2013. doi: http://dx.doi.org/10.1590/S1984-29612013000300008.

BUB, $\mathrm{H}$. Bird trapping and bird banding: a handbook for trapping methods all over the world. New York: Cornell University, $1991.330 \mathrm{p}$.

CÀCERES, A. G.; BEATI, L.; KEIRANS, J. E. First evidence of the occurrence of Amblyomma calcaratum Neumann, 1899 in Peru. Revista Peruana de Biología, v. 9, n. 2, p. 116-117, 2002.

CAPLIGINA, V.; SALMANE, I.; KEISS, O.; VILKS, K.; JAPINA, K.; BAUMANIS, V.; RANKA, R. Prevalence of tick-borne pathogens in ticks collected from migratory birds in Latvia. Ticks and Tick-borne Diseases, v. 5, n. 1, p. 75-81, 2014. doi: http://dx.doi.org/10.1016/j.ttbdis.2013.08.007. 
COMITÊ BRASILEIRO DE REGISTROS ORNITOLÓGICOS. (CBRO). Listas das aves do Brasil. 11. ed. 2014. Available from: <http://www.cbro.org.br>. Viewed: 29 Feb. 2016.

CONTI-DÍAZ, I. A.; MORAES-FILHO, J.; PACHECO, R. C.; LABRUNA, M. B. Serological evidence of Rickettsia parkeri as the etiological agent of rickettsiosis in Uruguay. Revista do Instituto de Medicina Tropical de São Paulo, v. $51, \quad$ n. $6, \quad$ p. 337-339, 2009. doi: http://dx.doi.org/10.1590/S0036-46652009000600005.

COOKSEY, L. M.; HAILE, D. G.; MOUNT, G. A. Computer simulation of Rocky Mountain spotted fever transmission by the American dog tick (Acari: Ixodidae). Journal of Medical Entomology, v. 27, n. 4, p. 671-680, 1990. doi: http://dx.doi.org/10.1093/jmedent/27.4.671.

CUNHA, R. G.; SILVA, R. A. Isolamento e identificação do vírus da doença de Newcastle no Brasil. Sociedade Brasileira de Medicina Veterinária, v. 23, p. 17-33, 1955.

DANIELS, T. J.; BATTALY, G. R.; LIVERIS, D.; FALCO, R. C.; SCHWARTZ, I. Avian reservoirs of the agent of Human Granulocytic Ehrlichiosis? Emerging Infectious Diseases, v. $8, \quad$ n. $12, \quad$ p. 1524-1525, 2002. doi: http://dx.doi.org/10.3201/eid0812.010527.

DANTAS-TORRES, F.; BERARDI, L. F. O.; SOUZASILVA, M.; FERREIRA, R. L.; ONOFRIO, V. C.; BARROSBATTESTI, D. M.; LABRUNA, M. B. New records of Ixodes paranaensis (Acari: Ixodidae) from Minas Gerais, southeastern Brazil. Systematic and Applied Acarology, v. 14, n. 3, p. 213-215, 2009a. doi: http://dx.doiorg/10.11158/saa.14.3.6.

DANTAS-TORRES, F.; FERREIRA, D. R. A.; MELO, L. M.; LIMA, P. C. P.; SIQUEIRA, D. B.; RAMEH-DEAlbuQUerQUe, L. C.; MELO, A. V.; RAMOS, J. A. C. Ticks on captive and free-living wild animals in northeastern Brazil. Experimental and Applied Acarology, v. 50, p. 181-189, 2010. doi: http://dx.doiorg/10.1007/s10493-0099296-5.

DANTAS-TORRES, F.; ONOFRIO, V. C.; BARROSBATTESTI, D. M. The ticks (Acari: Ixodida: Argasidae, Ixodidae) of Brazil. Systematic and Applied Acarology, v. 14, n. 1, p. 30-46, 2009b. doi: http://x.doiorg/10.11158/saa.14.1.4.

DANTAS-TORRES, F.; VENZAL, J. M.; BERNARDI, L. F. O.; FERREIRA, R. L.; ONOFRIO, V. C.; MARCILI, A.; BERMÚDEZ, S. E.; RIBEIRO, A. F.; BARROS-BATTESTI, D. M.; LABRUNA, M. B. Description of a new species of bat-associated argasid tick (Acari: Argasidae) from Brazil.
Journal of Parasitology, v. 98, n. 1, p. 36-45, 2012. doi: http://dx.doi.org/10.1645/GE-2840.1.

DEL HOYO, J.; ELLIOTT, A.; SARGATAL, J.; CHRISTIE, D. Handbook of the birds of the world. Barcelona: Lynx Edicions, 2013. 812 p.

DIOGO, A. A. R.; GUERIM, L.; PIRES, J. R.; COUTO, A. L. G.; SERRA-FREIRE, N. M. Parasitismo por Rhipicephalus sanguineus Latreille, 1806 em Columba livia Linnaeus na Cidade do Rio de Janeiro, Brazil. Entomologia y Vectores, v. 10, n. 2, p. 277-280, 2003.

DUBSKA, L.; LITERAK, I.; KOCIANOVA, E.; TARAGELOVA, V.; SYCHRA, O. Differential role of passerine birds in distribution of Borrelia spirochetes, based on data from ticks collected from birds during the postbreeding migration period in Central Europe. Applied and Enviromental Microbiology, v. 75, n. 3, p. 596-602, 2009. doi: http://dx.doi.org/ 10.1128/AEM.01674-08.

ELFVING, K.; OLSEN, B.; BERGSTRÖM, S.; WALDENSTRÖM, J.; LUNDKVIST, A.; SJÖSTEDT, A.; MEJLON, H.; NILSSON, K. Dissemination of spotted fever Rickettsia agents in Europe by migrating birds. PLoS One, v. 5, n. 1, p. e8572, 2010. doi: http://dx.doi.org/10.1371/journal.pone.0008572.

ENCINAS-NAGEL, N.; ENDERLEIN, D.; PIEPENBRING, A.; HERDEN, C.; HEFFELS-REDMANN, U.; FELIPPE, P. A.; ARNS, C.; HAFEZ, H. M.; LIERZ, M. Avian Bornavirus in free-ranging Psittacine birds, Brazil. Emerging Infectious Diseases, v. 20, n. 12, p. 2103-2106, 2014. doi: http://dx.doi.org/10.3201/eid2012.140920.

ERWIN, J. A.; FITAK, R. R.; DWYER, J. F.; MORRISON, J. L.; CULVER M. Molecular detection of bacteria in the families Rickettsiaceae and Anaplasmataceae in northern crested caracaras (Caracara cheriway). Ticks and Tickborne Diseases, v. 7, n. 3, p. 470-474, 2016, doi:10.1016/j.ttbdis.2016.01.015.

EVANS, D. E.; MARTINS, J. R.; GUGLIELMONE, A. A. A review of the ticks (Acari, Ixodida) of Brazil, their hosts and geographic distribution - 1. The State of Rio Grande do Sul, Southern Brazil. Memórias do Instituto Oswaldo Cruz, v. 95, n. 4, p. 453-470, 2000. doi: http://dx.doi.org/10.1590/S0074-02762000000400003.

FERRARI, F. A. G.; GODDARD, J.; MORARU, G. M.; SMITH, W. E. C.; VARELA-STOKES, A. S. Isolation of "Candidatus Rickettsia andeanae" (Rickettsiales: Rickettsiaceae) in embryonic cells of naturally infected Amblyomma maculatum (Ixodida: Ixodidae). Journal of 
Medical Entomology, v. 50, n. 5, p. 1118-1125, 2013. doi: http://dx.doi.org/10.1603/ME13010.

FLORES, F. S.; NAVA, S.; BATALLÁN, G.; TAURO, L. B.; CONTIGIANI, M. S.; DIAZ, L. A.; GUGLIELMONE, A. A. Ticks (Acari: Ixodidae) on wild birds in north-central Argentina. Ticks and Tick-borne Diseases, v. 5, n. 6, p. 715-721, 2014. doi: http://dx.doi.org/10.1016/j.ttbdis.2014.05.004.

FLORES-MENDOZA, C.; FLORIN, D.; FELICES, V.; POZO, E. J.; GRAF, P. C. F.; BURRUS, R. G.; RICHARDS, A. L. Detection of Rickettsia parkeri from within Piura, Peru, and the first reported presence of Candidatus Rickettsia andeanae in the tick Rhipicephalus sanguineus. Vector-Borne and Zoonotic Diseases, v. 13, n. 7, p. 505508, 2013. doi: http://dx.doi.org/10.1089/vbz.2012.1028.

FORNADEL, C. M.; ZHANG, X.; SMITH, J. D.; PADDOCK, C. D.; ARIAS, J. R.; NORRIS, D. E. High rates of Rickettsia parkeri infection in Gulf Coast ticks (Amblyomma maculatum) and identification of "Candidatus Rickettsia andeanae" from Fairfax County, Virginia. Vector-Borne and Zoonotic Diseases, v. 11, n. 12, p. 1535-1539, 2011. doi: http://dx.doi.org/10.1089/vbz.2011.0654.

GARCIA, M. V.; MATIAS, J.; AGUIRRE, A. A. R.; CSORDAS, B. G.; SZABÓ, M. P. J.; ANDREOTTI, R. Successful feeding of Amblyomma coelebs (Acari: Ixodidae) nymphs on humans in Brazil: skin reactions to parasitism. Journal of Medical Entomology, v. 52, n. 2, p. 117-119, 2015. doi: http://dx.doi.org/10.1093/jme/tju060.

GELLER, J.; NAZAROVA, L.; KATARGINA, O.; LEIVITS, A.; JÄRVEKÜLG, L.; GOLOVLJOVA, I. Tick-borne pathogens in ticks feeding on migratory passerines in Western part of Estonia. Vector-Borne and Zoonotic Diseases, v. 13, n. 7, p. 443-448, 2013. doi: http://dx.doi.org/10.1089/vbz.2012.1054.

GERN, L.; ESTRADA-PEÑA, A.; FRANDSEN, F.; GRAY, J. S.; JAENSON, T. G. T.; JONGEJAN, F.; KAHL, O.; KORENBERG, E.; MEHL, R.; NUTTALL, P. A. European reservoir hosts of Borrelia burgdorferi sensu lato. Zentralblatt für Bakteriologie, v. 287, n. 3, p. 196-204, 1998. doi: http://dx.doi.org/10.1016/S0934-8840(98)80121-7.

GONZÁLEZ-ACUÑA, D.; VENZAL, J. M.; KEIRANS, J. E.; ROBBINS, R. G.; IPPI, S.; GUGLIELMONE, A. A. New host and locality records for the Ixodes auritulus (Acari: Ixodidae) species group, with a review of host relationships and distribution in the Neotropical zoogeographic region. Experimental \& Applied Acarology, v. 37, n. 1, p. 147-156, 2005. doi: http://dx.doi.org/10.1007/s10493-005-8434-y.
GRAY, J.; DANTAS-TORRES, F.; ESTRADA-PEÑA, A.; LEVIN, M. Systematics and ecology of the brown dog tick, Rhipicephalus sanguineus. Ticks and Tick-borne Diseases, v. 4, n. 3, p. 171-180, 2013. doi: http://dx.doi.org/10.1016/j.ttbdis.2012.12.003.

GRESSLER, L. T.; PEREIRA, L. Q.; BRUSTOLIN, J. M.; LOVATO, M.; MONTEIRO, S. G. Occurrence of Amblyomma longirostre in Cyanocompsa brissonii in Rio Grande do Sul, Brazil. Ciência Rural, v. 46, n. 4, p. 660-662, 2016. doi: http://dx.doi.org/10.1590/0103-8478cr20150636.

GUGLIELMONE, A. A.; BEATI, L.; BARROS-BATTESTI, D. M.; LABRUNA, M. B.; NAVA, S.; VENZAL, J. M.; MANGOLD, A. J.; SZABÓ, M. P. J.; MARTINS, J. R.; GONZÁLEZ-ACUÑA, D.; ESTRADA-PEÑA, A. Ticks (Ixodidae) on humans in South America. Experimental \& Applied Acarology, v. 40, n. 2, p. 83-100, 2006. doi: http://dx.doi.org/10.1007/s10493-006-9027-0.

GUGLIELMONE, A. A.; ESTRADA-PEÑA, A.; LUCIANI, C. A.; MANGOLD, A. J.; KEIRANS, J. E. Hosts and distribution of Amblyomma auricularium (Conil 1878) and Amblyomma pseudoconcolor Aragão, 1908 (Acari: Ixodidae). Experimental \& Applied Acarology, v. 29, n. 1, p. 131-139, 2003. doi: http://dx.doi.org/10.1023/A:1024251020035.

GUGLIELMONE, A. A.; ROBBINS, R. G.; APANASKEVICH, D. A.; PETNEY, T. N.; ESTRADAPEÑA, A.; HORAK, I. G. The hard ticks of the world: (Acari: Ixodida: Ixodidae). Dordrecht, Heidelberg, New York, London: Springer, 2014. 738 p. doi: http://dx.doi.org/10.1007/978-94-007-7497-1.

HAMER, S. A.; HICKLING, G. J.; KEITH, R.; SIDGE, J. L.; WALKER, E. D.; TSAO, J. I. Associations of passerine birds, rabbits, and ticks with Borrelia miyamotoi and Borrelia andersonii in Michigan, U.S.A. Parasites \& Vectors, v. 5, n. 231, p. 1-11, 2012. doi: http://dx.doi.org/10.1186/1756-3305-5-231.

HAMER, S. A.; HICKLING, G. J.; SIDGE J. E.; ROSEN, M. E.; WALKER, E. D.; TSAO, J. I. Diverse Borrelia burgdorferi strains in a bird-tick cryptic cycle. Applied and Environmental Microbiology, v. 77, n. 6, p. 1999-2007, 2011. doi: http://dx.doi.org/10.1128/AEM.02479-10.

HASLE, G. Transport of ixodid ticks and tick-borne pathogens by migratory birds. Frontiers in Cellular and Infection Microbiology, v. 3, n. 48, p. 1-6, 2013. doi: http://dx.doi.org/10.3389/fcimb.2013.00048.

HASLE, G.; BJUNE, G. A.; MIDTHJELL, L.; ROED, K. H.; LEINAAS, H. P. Transport of Ixodes ricinus infected with Borrelia species to Norway by northward-migrating 
passerine birds. Ticks and Tick-borne Diseases, v. 2, n. 1, p. 37-43, 2011. doi: http://dx.doi.org/10.1016/j.ttbdis.2010.10.004.

HILDEBRANDT, A.; FRANKE, J.; MEIER, F.; SACHSE, S.; DORN, W.; STRAUBE, E. The potential role of migratory birds in transmission cycles of Babesia spp., Anaplasma phagocytophilum, and Rickettsia spp. Ticks and Tick-borne Diseases, v. 1, n. 2, p. 105-107, 2010. doi: http://dx.doi.org/10.1016/j.ttbdis.2009.12.003.

HOOGSTRAAL, H.; KAISER, M. N.; TRAYLOR, M. A.; GABER, S.; GUINDY, E. Ticks (Ixodoidea) on birds migrating from Africa to Europe and Asia. Bulletin of the World Health Organization, v. 24, n. 2, p. 197-212, 1961.

HOOGSTRAAL, H.; KAISER, M. N.; TRAYLOR, M. A.; QUINDY, E.; GABER, S. Ticks (Ixodidae) on birds migrating from Europe and Asia to Africa, 1959-61. Bulletin of the World Health Organization, v. 28, n. 2, p. 235-262, 1963.

HORNOK, S.; KOVÁTS, D.; CSÖRGÖ, T.; MELI, M. L.; GÖNCZI, E.; HADNAGY, Z.; TAKÁCS, N.; FARKAS, R.; HOFMANN-LEHMANN, R. Birds as potential reservoirs of tick-borne pathogens: first evidence of bacteraemia with Rickettsia helvetica. Parasites \& Vectors, v. 7, n. 128, p. 1-7, 2014. doi: http://dx.doi.org/10.1186/1756-3305-7-128.

HORTA, M. C.; LABRUNA, M. B.; PINTER, A.; LINARDI, P. M.; SCHUMAKER, T. T. S. Rickettsia infection in five areas of the state of São Paulo, Brazil. Memórias do Instituto Oswaldo Cruz, v. 102, n. 7, p. 793-801, 2007. doi: http://dx.doi.org/10.1590/S0074-02762007000700003.

HORTA, M. C.; NASCIMENTO, G. F.; MARTINS, T. F.; LABRUNA, M. B.; MACHADO, L. C. P.; NICOLA, P. A. Ticks (Acari: Ixodida) parasitizing free-living wild animals in the Caatinga biome in the State of Pernambuco, northeastern Brazil. Systematic and Applied Acarology Society, v. 16, n. 3, p. 207-211, 2011. doi: http://dx.doi.org/10.11158/saa.16.3.3.

HORTA, M. C.; PINTER, A.; SCHUMAKER, T. T. S.; LABRUNA, M. B. Natural infection, transovarial transmission, and transstadial survival of Rickettsia bellii in the tick Ixodes loricatus (Acari: Ixodidae) from Brazil. Annals of the New York Academy of Science, v. 1078, n. 1, p. 285-290, 2006. doi: http://dx.doi.org/10.1196/annals.1374.053.

HUBÁLEK, Z. An annotated checklist of pathogenic microorganisms associated with migratory birds. Journal of Wildlife Diseases, v. 40, n. 4, p. 639-659, 2004. doi: http://dx.doi.org/10.7589/0090-3558-40.4.639.
HUMAIR, P. F.; POSTIC, D.; WALLICH, R.; GERN, L. An avian reservoir (Turdus merula) of the Lyme borreliosis spirochetes. Zentralblatt für Bakteriologie, v. 287, n. 4, p. 521-538, 1998. doi: http://dx.doi.org/10.1016/S09348840(98)80194-1.

HUN, L.; CORTÉS X.; TAYLOR, L. Molecular characterization of Rickettsia rickettsii isolated from human clinical samples and from the rabbit tick Haemaphysalis leporispalustris collected at different geographic zones in Costa Rica. American Journal of Tropical Medicine and Hygiene, v. 79, n. 6, p. 899-902, 2008.

HUN, L.; TROYO, A.; TAYLOR, L.; BARBIERI, A. M.; LABRUNA, M. B. First report of the isolation and molecular characterization of Rickettsia amblyommii and Rickettsia felis in Central America. Vector-Borne and Zoonotic Diseases, v. 11, n. 10, p. 1395-1397, 2011. doi: http://dx.doi.org/10.1089/vbz.2011.0641.

IOANNOU, I.; CHOCHLAKIS, D.; KASINIS, N.; ANAYIOTOS, P.; LYSSANDROU, A.; PAPADOPOULOS, B.; TSELENTIS, Y.; PSAROULAKI, A. Carriage of Rickettsia spp., Coxiella burnetii and Anaplasma spp. by endemic and migratory wild birds and their ectoparasites in Cyprus. Clinical Microbiology and Infection, v. 15, p. 158160, 2009. Supplement 2. doi: http://dx.doi.org/10.1111/j.1469-0691.2008.02207.x.

JIANG, J.; BLAIR, P. J.; FELICES, V.; MORON, C.; CESPEDES, M.; ANAYA, E.; SCHOELER, G. B.; SUMNER, J. W.; OLSON, J. G.; RICHARDS, A. L. Phylogenetic analysis of a novel molecular isolate of spotted fever group rickettsiae from northern Peru: Candidatus Rickettsia andeanae. Annals of the New York Academy of Sciences, v. 1063, p. 337-342, $2005 . \quad$ doi: http://dx.doi.org/10.1196/annals.1355.054.

JIANG, J.; STROMDAHL, E. Y.; RICHARDS, A. L. Detection of Rickettsia parkeri and Candidatus Rickettsia andeanae in Amblyomma maculatum Gulf Coast ticks collected from humans in the United States. Vector-Borne and Zoonotic Diseases, v. 12, n. 3, p. 175-182, 2012. doi: http://dx.doi.org/10.1089/vbz.2011.0614.

JIANG, J.; YARINA, T.; MILLER, M. K.; STROMDAHL, E. Y.; RICHARDS, A. L. Molecular detection of Rickettsia amblyommii in Amblyomma americanum parasitizing humans. Vector-Borne and Zoonotic Diseases, v. 10, n. 4, p. 329-340, 2010. doi: http:/dx.doiorg/10.1089/vbz2009.0061.

JONES, E. K.; CLIFFORD, C. M.; KEIRANS, J. E.; KOHLS, G. M. The ticks of Venezuela (Acarina: Ixodoidea) with a key to the species of Amblyomma in the Western 
Hemisphere. Brigham Young University Science Bulletin: Biological Series, v. 17, n. 4, p. 1-40, 1972.

JONGEJAN, F.; UILENBERG, G. The global importance of ticks. Parasitology, v. 129, p. S3-S14, 2004. Supplement 1. doi: http://dx.doi.org/10.1017/S0031182004005967.

KINSEY, A. A.; DURDEN, L. A.; OLIVER JUNIOR, J. H. Tick infestations of birds in coastal Georgia and Alabama. Journal of Parasitology, v. 86, n. 2, p. 251-254, 2000. doi: http://dx.doi.org/10.1645/0022-3395(2000)086[0251:TIOBIC]2.0.CO;2.

KJELLAND, V.; STUEN, S.; SKARPAAS, T.; SLETTAN, A. Prevalence and genotypes of Borrelia burgdorferi sensu lato infection in Ixodes ricinus ticks in southern Norway. Scandinavian Journal of Infectious Diseases, v. 42, n. 8, p. 579-585, 2010. doi: http://dx.doi.org/10.3109/00365541003716526.

KLICH, M.; LANKESTER, W. M.; WU, K. W. Spring migratory birds (Aves) extend the northern occurrence of blacklegged tick (Acari: Ixodidae). Journal of Medical Entomology, v. 33, n. 4, p. 581-585, 1996 . doi: http://dx.doi.org/10.1093/jmedent/33.4.581.

KOHLS, G. M.; CLIFFORD, C. M.; JONES, E. K. The systematics of the sub family Ornithodorinae (Acarina: Argasidae). IV. Eight new species of Ornithodoros from the Western Hemisphere. Annals of the Entomological Society of America, v. 62, n. 5, p. 1035-1043, 1969.

KRAWCZAK, F. S.; MARTINS, T. F.; OLIVEIRA, C. S.; BINDER, L. C.; COSTA, F. B.; NUNES, P. H.; GREGORI, F.; LABRUNA, M. B. Amblyomma yucumense n. sp. (Acari: Ixodidae), a parasite of wild mammals in Southern Brazil. Journal of Medical Entomology, v. 52, n. 1, p. 28-37, 2015. doi: http://dx.doi.org/10.1093/jme/tju007.

KRAWCZAK, F. S.; NIERI-BASTOS, F. A.; NUNES, F. P.; SOARES, J. F.; MORAES-FILHO, J.; LABRUNA, M. B. Rickettsial infection in Amblyomma cajennense ticks and capybaras (Hydrochoerus hydrochaeris) in a Brazilian spotted fever-endemic area. Parasites \& Vectors, v. 7, p. 17, 2014. doi: http://dx.doi.org/10.1186/1756-3305-7-7.

LABRUNA, M. B. Ecology of Rickettsia in South America. Annals of the New York Academy of Sciences, v. 1166, p. 156-166, 2009. doi: http://dx.doi.org/10.1111/j.17496632.2009.04516.x.

LABRUNA, M. B.; CAMARGO, L. M. A.; TERRASSINI, F. A.; SCHUMAKER, T. T. S.; CAMARGO, E. P. Notes on parasitism by Amblyomma humerale (Acari: Ixodidae) in the state of Rondônia, Western Amazon, Brazil. Journal of
Medical Entomology, v. 39, n. 6, p. 814-817, 2002b. doi: http://dx.doi.org/10.1603/0022-2585-39.6.814.

LABRUNA, M. B.; CAMARGO, L. M. A.; TERASSINI, F. A.; FERREIRA, F.; SCHUMAKER, T. T. S.; CAMARGO, E. P. Ticks (Acari: Ixodidae) from the State of Rondônia, western Amazon, Brazil. Systematic and Applied Acarology, v. 10, n. 1, p. 17-32, 2005a. doi: http://dx.doi.org/10.11158/saa.10.1.5.

LABRUNA, M. B.; CAMARGO, L. M.; CAMARGO, E. P.; WALKER, D. H. Detection of a spotted fever group Rickettsia in the tick Haemaphysalis juxtakochi in Rondônia, Brazil. Veterinary Parasitology, v. 127, n. 2, 169-174, 2005c. doi: http://10.1016/j.vetpar.2004.09.024.

LABRUNA, M. B.; FUGISAKI, E. Y.; PINTER, A.; DUARTE, J. M.; SZABÓ, M. J. Life cycle and host specificity of Amblyomma triste (Acari: Ixodidae) under laboratory conditions. Experimental and Applied Acarology, v. 30, p. 305-316, 2003.

LABRUNA, M. B.; HORTA, M. C.; AGUIRAR, D. M.; CAVAlCANTE, G. T.; PINTER, A.; GENNARI, S. M.; CAMARGO, L. M. A. Prevalence of Rickettsia infection in dogs from the urban and rural areas of Monte Negro Municipality, Western Amazon, Brazil. Vector-Borne and Zoonotic Diseases, v. 7, n. 2, p. 249-256, 2007d. doi: http://dx.doi.org/10.1089/vbz.2006.0621.

LABRUNA, M. B.; JORGE, R. S. P.; SANA, D. A.; JACOMO, A. T. A.; KASHIVAKURA, C. K.; FURTADO, M. M.; FERRO, C.; PEREZ, S. A.; SILVEIRA, L.; SANTOS, T. S.; MARQUES, S. R.; MORATO, R. G.; NAVA, A.; ADANIA, C. H.; TEIXEIRA, R. H. F.; GOMES, A. A. B.; CONFORTI, V. A.; AZEVEDO, F. C. C.; PRADA, C. S.; SILVA, J. C. R.; BATISTA, A. F.; MARVUlO, M. F. V.; MORATO, R. L. G.; ALHO, C. J. R.; PINTER, A.; FERREIRA, P. M.; FERREIRA, F.; BARROS-BATTESTI, D. M. Ticks (Acari: Ixodida) on wild carnivores in Brazil. Experimental and Applied Acarology, v. 36, n. 1-2, p. 149163, 2005b. doi: http://dx.doi.org/10.1007/s10493-005-2563-1.

LABRUNA, M. B.; MARCILI, A.; OGRZEWALSKA, M.; BARROS-BATTESTI, D. M.; DANTAS-TORRES, F.; FERNANDES, A. A.; LEITE, R. C.; VENZAL, J. M. New records and human parasitism by Ornithodoros mimon (Acari: Argasidae) in Brazil. Journal of Medical Entomology, v. 51, n. 1, p. 283-287, 2014. doi: http://dx.doi.org/10.1603/ME13062.

LABRUNA, M. B.; MCBRIDE, J. W.; BOUYER, D. H.; CAMARGO, L. M.; CAMARGO, E. P.; WALKER, D. H. Molecular evidence for a spotted fever group Rickettsia 
species in the tick Amblyomma longirostre in Brazil. Journal of Medical Entomology, v. 41, n. 3, p. 533-537, 2004c. doi: http://dx.doi.org/10.1603/0022-2585-41.3.533.

LABRUNA, M. B.; ONOFRIO, V. C.; BEATI, L.; ARZUA, M.; BERTOLA, P. B.; RIBEIRO, A. F.; BARROSBATTESTI, D. B. Redescription of the female, description of the male, and several new records of Amblyomma parkeri (Acari: Ixodidae), a South American tick species. Experimental and Applied Acarology, v. 49, n. 3, p. 243260, 2009. doi: http://dx.doi.org/10.1007/s10493-009-9257-z

LABRUNA, M. B.; PACHECO, R. C.; RICHTZENHAIN, L. J.; SZABÓ, M. P. J. Isolation of Rickettsia rhipicephali and Rickettsia bellii from Haemaphysalis juxtakochi Ticks in the State of São Paulo, Brazil. Applied and Environmental Microbiology, v. 73 n. 3, p. 869-873, 2007b. doi: http://dx.doi.org/10.1128/AEM.02249-06.

LABRUNA, M. B.; PAULA, C. D.; LIMA, T. F.; SANA, D. A. Ticks (Acari: Ixodidae) on wild animals from the PortoPrimavera hydroelectric power station area, Brazil. Memórias do Instituto Oswaldo Cruz, v. 97, n. 8, p. 11331136, 2002a. doi: http://dx.doi.org/10.1590/S007402762002000800012 .

LABRUNA, M. B.; ROMERO, M.; MARTINS, T. F.; TOBLER, M.; FERREIRA, F. Ticks of the genus Amblyomma (Acari: Ixodidae) infesting tapirs (Tapirus terrestris) and peccaries (Tayassu pecari) in Peru. Systematic and Applied Acarology, v. 15, n. 2, p. 109-112, 2010. doi: http://dx.doi.org/10.11158/saa.15.2.3.

LABRUNA, M. B.; SANFILIPPO, L. F.; DEMETRIO, C.; MENEZES, A. C.; PINTER, A.; GUGLIELMONE, A. A.; SILVEIRA, L. F. Ticks collected on birds in the state of São Paulo, Brazil. Experimental and Applied Acarology, v. 43, n. 2, p. 147-160, 2007a. doi: http://dx.doi.org/ 10.1007/s10493-007-9106-x.

LABRUNA, M. B.; VENZAL, J. M. Carios fonsecai sp. nov. (Acari, Argasidae), a bat tick from the central western region of Brazil. Acta Parasitológica, v. 54, n. 4, p. 355-363, 2009. doi: http://dx.doi.org/10.2478/s11686-009-0051-1.

LABRUNA, M. B.; WHITWORTH, T.; BOUYER, D. H.; MCBRIDE, J.; CAMARGO, L. M. A.; CAMARGO, E. P.; POPOV, V.; WALKER, D. H. Rickettsia bellii and Candidatus Rickettsia amblyommii in Amblyomma ticks from the State of Rondônia, Western Amazon, Brazil. Journal of Medical Entomology, v. 41, n. 6, p. 1073-1081, 2004a. doi: http://dx.doi.org/10.1603/0022-2585-41.6.1073.
LABRUNA, M. B.; WHITWORTH, T.; HORTA, M. C.; BOUYER, D. H.; MCBRIDE, J. W.; PINTER, A.; POPOV, V.; GENNARI, S. M.; WALKER, D. H. Rickettsia species infecting Amblyomma cooperi ticks from an area in the state of Sao Paulo, Brazil, where Brazilian spotted fever is endemic. Journal of Clinical Microbiology, v. 42, n. 1, p. 90-98, 2004b. doi: http://dx.doi.org/10.1128/JCM.42.1.9098.2004 .

LANDUlFO, G. A.; PEVIDOR, L. V.; SAMPAIO, J. S.; LUZ, H. R.; ONOFRIO, V. C.; FACCINI, J. L. H.; BARROSBATTESTI, D. M. Life cycle of Ornithodoros mimon (Acari: Argasidae) under laboratory conditions. Experimental and Applied Acarology, v. 58, n. 1, p. 69-80, 2012. doi: http://dx.doi.org/10.1007/s10493-012-9567-4.

LITERAK, I.; NORTE, A. C.; NÚNCIO, M. S.; DE CARVALHO, I. L.; OGRZEWALSKA, M.; NOVÁKOVÁ, M.; MARTINS, T. F.; SYCHRA, O.; RESENDES, R.; RODRÍGUES, P. Ticks on passerines from the Archipelago of the Azores as hosts of borreliae and rickettsiae. Ticks and Tick Borne Diseases, v. 6, n. 5, p. 607-610, 2015. doi: http://dx.doi.org/10.1016/j.ttbdis.2015.05.003.

LOPES, L. B.; GUTERRES, A.; ROZENTAL, T.; OLIVEIRA, R. C.; MARES-GUIA, M. A.; FERNANDES, J.; FIGUEREDO, J. F.; ANSCHAU, I.; JESUS, S.; ALMEIDA, A. B. M. V.; SILVA, V. C.; VIA, A. V. G. M.; BONVICINO, C. R.; D'ANDREA, P. S.; BARREIRA, J. D.; LEMOS, E. R. S. Rickettsia bellii, Rickettsia amblyommii, and Laguna Negra hantavirus in an Indian reserve in the Brazilian Amazon. Parasites and Vectors, v. 7, p. 191, 2014. doi: http://dx.doi.org/10.1186/1756-3305-7-191.

LOROSA, E. S.; ANDRADE, R. E.; VALENTE, M. V. M.; FARIA, M. S.; CRUZ, J. R.; GAZETA, G. S. Inespecificidade parasitária em Argas (Persicargas) miniatus Koch, 1844 (Acari: Argasidae). Arquivo Brasileiro de Medicina Veterinária e Zootecnia, v. 59, n. 6, p. 1485-1488, 2007. doi: http://dx.doi.org/10.1016/j.ttbdis.2015.05.003.

LOUREIRO, M. C.; JUNQUEIRA NETO, D. Incidência de Argas miniatus Koch no município de Matosinhos, Minas Gerais. Pesquisa Agropecuária Brasileira, v. 1, n. 1, p. 185$187,1966$.

LUGARINI, C.; MARTINS, T. F.; OGRZEWALSKA, M.; DE VASCONCELOS, N. C.; ELLIS, V. A.; DE OLIVEIRA J. B.; PINTER, A.; LABRUNA, M. B.; SILVA, J. C. Rickettsial agents in avian ixodid ticks in northeast Brazil. Ticks and Tick-borne Diseases, v. 6, n. 3, p. 364-375, 2015. doi: http://dx.doi.org/10.1016/j.ttbdis.2015.02.011. 
LUNDGREN, D. L.; THORPE, B. D; HASKELL. C. D. Infectious diseases in wild animals in Utah. VI. Experimental infection of birds with Rickettsia rickettsii. Journal of Bacteriology, v. 91, n. 3, p. 963-966, 1966.

LUZ, H. R.; FACCINI, J. L. H. Ticks on Brazilian birds: overview. In: RUIZ, L.; IGLESIAS, F. (Ed.). Birds: evolution and behavior, breeding strategies, migration and spread of disease. New York: Nova Science, 2013. p. 97-126.

LUZ, H. R.; FACCINI, J. L. H.; LANDUlFO, G. A.; BERTO, B. P.; FERREIRA, I. Bird ticks in an area of the Cerrado of Minas Gerais State, southeast Brazil. Experimental and Applied Acarology, v. 58, n. 1, p. 89-99, 2012. doi: http://dx.doi.org/10.1007/s10493-012-9572-7.

MACIEL, J. F.; KRAWCZAK DA SILVA, F.; SOBOTYK DE OILIVEIRA, C.; MORAES-FILHO, J.; LABRUNA, M. B.; BOTTON DE AVILA, S.; SILVEIRA FLORES VOGEL, F.; SANGIONI, L. A. Detection of anti: Rickettsia spp. antibodies in domestic chickens of extensive breeding in an endemic area for spotted fever in the state of Rio Grande do Sul, Brazil. Ciência Rural, v. 43, n. 11, p. 2037-2041, 2013. doi: http://dx.doi.org/10.1590/S0103-84782013005000123.

MANGOLD, A. J.; BARGUES, M. D.; MAS-COMA, S. Mitochondrial 16S rDNA sequences and phylogenetic relationships of species of Rhipicephalus and other tick genera among Metastriata (Acari: Ixodidae). Parasitology Research, v. 84, n. 6, p. 478-484, 1998. doi: http://dx.doi.org/10.1007/s004360050433.

MARQUES, S.; BARROS-BATTESTI, D. M.; FACCINI, J. L. H.; ONOFRIO, V. C. Brazilian distribution of Amblyomma varium Koch, 1844 (Acari:Ixodidae), a common parasite of sloths (Mammalia: Xenarthra). Memórias do Instituto Oswaldo Cruz, v. 97, n. 8, p. 11411146, 2002. doi: http://dx.doi.org/10.1590/S007402762002000800014

MARTINS, T. F.; FECCHIO, A.; LABRUNA, M. B. Ticks of the genus Amblyomma (Acari: Ixodidae) on wild birds in the Brazilian Amazon. Systematic and Applied Acarology, v. 19, n. 4, p.385-392, 2014b. doi:http://dx.doi.org/10.11158/saa.19.4.1.

MARTINS, T. F.; ONOFRIO, V. C.; BARROS-BATTESTI, D. M.; LABRUNA, M. B. Nymphs of the genus Amblyomma (Acari: Ixodidae) of Brazil: descriptions, redescriptions, and identification key. Ticks and Tickborne Diseases, v. 1, n. 2, p. 75-99, 2010. doi: http://dx.doi.org/10.1016/j.ttbdis.2010.03.002.
MARTINS, T. F.; SCOFIELD, A.; OLIVEIRA, W. B.; NUNES, P. H.; RAMIREZ, D. G.; BARROS-BATTESTI, D. M.; SÁ, L. R.; AMPUERO, F.; SOUZA JR., J. C.; LABRUNA, M. B. Morphological description of the nymphal stage of Amblyomma geayi and new nymphal records of Amblyomma parkeri. Ticks and Tick-borne Diseases, v. 4, n. 3, p. 181-184, 2013. doi: http://dx.doi.org/10.1016/j.ttbdis.2012.11.015.

MARTINS, T. F.; VENZAL, J. M.; TERASSINI, F. A.; COSTA, F. B.; MARCILI, A.; CAMARGO, L. M.; BARROSBATTESTI, D. M.; LABRUNA, M. B. New tick records from the state of Rondônia, western Amazon, Brazil. Experimental and Applied Acarology, v. 62, n. 1, p. 121128, 2014a. doi: http://dx.doi.org/10.1007/s10493-013-9724-4.

MARTINS, T.; FURTADO, M.; JÁCOMO, A.; SILVEIRA, L.; SOLLMANN, R.; TORRES, N.; LABRUNA, M. Ticks on free-living wild mammals in Emas National Park, Goiás State, central Brazil. Systematic and Applied Acarology, v. 16, n. 3, p. 201-206, 2011. doi: http:/dx.doi.org/10.11158/saa.163.2.

MCINTOSH, D.; BEZERRA, R. A.; LUZ, H. R.; FACCINI, J. L. H.; GAIOTTO, F. A.; FERNANDEZ GINÉ, G. A.; ALBUQUERQUE, G. R. Detection of Rickettsia bellii and Rickettsia amblyommii in Amblyomma longirostre (Acari: Ixodidae) from Bahia state, Northeast Brazil. Brazilian Journal of Microbiology, v. 46, n. 3, p. 879-883, 2015. doi: http://dx.doi.org/10.1590/S1517-838246320140623.

MEDEIROS, A. P.; DE SOUZA, A. P.; DE MOURA, A. B.; LAVINA, M. S.; BELLATO, V.; SARTOR, A. A.; NIERIBASTOS, F. A.; RICHTZEHAIN, L. J.; LABRUNA, M. B. Spotted fever group Rickettsia infecting ticks (Acari: Ixodidae) in the state of Santa Catarina, Brazil. Memórias do Instituto Oswaldo Cruz, v. 106, n. 8, p. 926-930, 2011. doi: http://dx.doi.org/10.1590/S0074-02762011000800005.

MELO, A. L. T.; ALVES, A. S.; NIERI-BASTOS, F. A.; MARTINS, T. F.; WITTER, R.; PACHECO, T. A.; SOARES, H. S.; MARCILI, A.; CHITARRA, C. S.; DUTRA, V.; NAKAZATO, L.; PACHECO, R. C.; LABRUNA, M. B.; AGUIAR, D. M. Rickettsia parkeri infecting free-living Amblyomma triste ticks in the Brazilian Pantanal. Ticks and Tick-borne Diseases, v. 6, n. 3, p. 237-241, 2015. doi: http://dx.doi.org/10.1016/j.ttbdis.2015.01.002.

MERTINS, J. W.; MOORHOUSE, A. S.; ALFRED, J. T.; HUTCHESON, H. J. Amblyomma triste (Acari: Ixodidae): new North American collection records, including the first from the United States Journal of Medical Entomology, v. 47, p. 536-542, 2010.

MIRANDA, J.; PORTILlO, A.; OTEO, J. A.; MATTAR, S. Rickettsia sp. strain colombianensi (Rickettsiales: 
Rickettsiaceae): a new proposed Rickettsia detected in Amblyomma dissimile (Acari: Ixodidae) from iguanas and free-living larvae ticks from vegetation. Journal of Medical Entomology, v. 49, n. 4, p. 960-965, 2012. doi: http://dx.doi.org/10.1603/ME11195.

MONCAYO, A. C.; COHEN, S. B.; FRITZEN, C. M.; HUANG, E.; YABSLEY, M. J.; FREYE, J. D.; DUNLAP, B. G.; HUANG, J.; MEAD, D. G.; JONES, T. F.; DUNN, J R. Absence of Rickettsia rickettsii and occurrence of other spotted fever group rickettsiae in ticks from Tennessee. American Journal of Tropical Medicine and Hygiene, v. 83,n.3,p. 653-657,2010. doi:http:/dx.doi.org/10.4269/ajtmh.2010.09-0197.

MORAES-FILHO, J.; MARCILI, A.; NIERI-BASTOS, F. A.; RICHTZENHAIN, L. J.; LABRUNA, M. B. Genetic analysis of ticks belonging to the Rhipicephalus sanguineus group in Latin America. Acta Tropica, v. 117, n. 1, p. 51-55, 2011. doi: http://dx.doi.org/10.1016/j.actatropica.2010.09.006.

MORAES-FILHO, J.; PINTER, A.; PACHECO, R. C.; GUTMANN, T. B.; BARBOSA, S. O.; GONZÁLES, M. A.; MURARO, M. A.; CECÍlIO, S. R.; LABRUNA, M. B. New epidemiological data on Brazilian spotted fever in an endemic area of the state of São Paulo, Brazil. VectorBorne and Zoonotic Diseases, v. 9, n. 1, p. 73-78, 2009. doi: http://dx.doi.org/10.1089/vbz.2007.0227.

MORARU, G. M.; GODDARD, J.; PADDOCK, C. D.; VARELA-STOKES, A. Experimental infection of cotton rats and bobwhite quail with Rickettsia parkeri. Parasites and Vectors, v. 6, p. 70, 2013. doi: http://dx.doi.org/10.1186/1756-3305-6-70.

MORSHED, M. G.; SCOTT, J. D.; FERNANDO, K.; BEATI, L.; MAZEROLLE, D. F.; GEDDES, G.; DURDEN, L.A. Migratory songbirds disperse ticks across Canada, and first isolation of the Lyme disease spirochete, Borrelia burgdorferi, from the avian tick, Ixodes auritulus. Journal of Parasitology, v. 91, n. 4, p. 780-790, 2005. doi: http://dx.doi.org/10.1645/GE-3437.1.

MOVILA, A.; REYE, A. L; DUBININA, H. V.; TOLSTENKOV, O. O.; TODERAS, I.; HUBSCHEN, J. M.; MULLER, C. P.; ALEKSEEV, A. N. Detection of Babesia sp. EU1 and members of spotted fever group rickettsiae in ticks collected from migratory birds at Curonian Spit, NorthWestern Russia. Vector-Borne Zoonotic Diseases, v. 11, n. 1, p. 89-91, 2011. doi: http://dx.doi.org/10.1089/vbz.2010.0043.

MUKHERJEE, N.; BEATI, L.; SELLERS, M.; BURTON, L.; ADAMSON, S.; ROBBINS, R. G.; MOORE, F.; KARIM, S. Importation of exotic ticks and tick-borne spotted fever group rickettsiae into the United States by migrating songbirds. Ticks and Tick-borne Diseases, v. 5 n. 2, p. 127 134, 2014. doi: http://dx.doi.org/10.1016/j.ttbdis.2013.09.009.

MULLINS, M. C.; LAZZARINI, S. M.; PICANÇO, M. C. L.; SERRA-FREIRE, N. Amblyomma parvum a parasite of Dasypus kappleri in the state of Amazonas, Brazil. Revista de Ciências Agrarias, v. 42, p. 287-291, 2004.

MURGAS, I. L; CASTRO, A. M.; BERMÚdEZ, S. E. Current status of Amblyomma ovale (Acari: Ixodidae) in Panama. Ticks and Tick-borne Diseases, v. 4, n. 1-2, p. 164-166, 2013. http://dx.doi.org/10.1016/j.ttbdis.2012.09.002.

NADOLNY, R. M.; WRIGHT, C. L.; SONENSHINE, D. E.; HYNES, W. L.; GAFF, H. D. Ticks and spotted fever group rickettsiae of southeastern Virginia. Ticks and Tick-borne Diseases, v. 5, n. 1, p. 53-57, 2014. http://dx.doi.org/10.1016/j.ttbdis.2013.09.001.

NAVA, S.; BEATI, L.; LABRUNA, M. B.; CÁCERES, A. G.; MANGOLD, A. J.; GUGLIELMONE, A. A. Reassessment of the taxonomic status of Amblyomma cajennense (Fabricius, 1787) with the description of three new species, Amblyomma tonelliae n. sp., Amblyomma interandinum n. sp. and Amblyomma patinoi n. sp., and resurrection of Amblyomma mixtum Koch, 1844 and Amblyomma sculptum Berlese, 1888 (Ixodida: Ixodidae). Ticks and Tickborne Diseases, v. 5, p. 252-276. 2014. http://dx.doi.org/10.1016/j.ttbdis.2013.11.004.

NAVA, S.; ELSHENAWY, Y.; EREMEEVA, M. E.; SUMNER, J. W.; MASTROPAOLO, M.; PADDOCK, C. D. Rickettsia parkeri in Argentina. Emerging Infectious Diseases, v. 14, n. 12, p. 1894-1897, 2008a. doi: http://dx.doi.org/10.3201/eid1412.080860.

NAVA, S.; ESTRADA-PEÑA, A.; PETNEY, T.; BEATI, L.; LABRUNA, M. B.; SZABÓ, M. P.; VENZAL, J. M.; MASTROPAOLO, M.; MANGOLD, A. J.; GUGLIELMONE, A. A. The taxonomic status of Rhipicephalus sanguineus (Latreille, 1806). Veterinary Parasitology, v. 208, n. 1-2, p. 2-8, 2015. doi: http://dx.doi.org/10.1016/j.vetpar.2014.12.021.

NAVA, S.; MANGOLD, A. J.; GUGLIELMONE, A. A. The natural hosts for larvae and nymphs of Amblyomma neumanni and Amblyomma parvum (Acari: Ixodidae). Experimental and Applied Acarology, v. 40, n. 2, p. 123131, 2006. doi: http://dx.doi.org/10.1007/s10493-006-9026-1.

NAVA, S.; MANGOLD, A. J.; MASTROPAOLO, M.; VENZAL, J. M.; FRACASSI, N.; GUGLIELMONE, A. A. Seasonal dynamics and hosts of Amblyomma triste (Acari: 
Ixodidae) in Argentina. Veterinary Parasitology, v. 181, n. 2-4,p.301-308,2011. doi: http:// dx.doi.org/10.1016/j.vetpar.2011.03.054.

NAVA, S.; SZABÓ, M. P. J.; MANGOLD, A. J.; GUGLIELMONE, A. A. Distribution, hosts, 16S rDNA sequences and phylogenetic position of the Neotropical tick Amblyomma parvum (Acari: Ixodidae). Annals of Tropical Medicine and Parasitology, v. 102, n. 5, p. 102, 409-425, 2008b. doi: http://dx.doi.org/10.1179/136485908X278883.

NAVA, S.; VELAZCO, P. M.; GUGLIEMONE, E. E. First record of Amblyomma longirostre (Koch 1844) (Acari: Ixodidae) from Peru, with a review of this tick's host relationships. Systematic and Applied Acarology, v. 15, n. 1, p. 21-30, 2010b. doi: http://dx.doi.org/10.11158/saa.15.1.2.

NAVA, S.; VENZAL, J. M.; TERASSINI, F. A.; MANGOLD, A. J.; CAMARGO, L. M.; LABRUNA, M. B. Description of a new argasid tick (Acari: Ixodida) from bat caves in Brazilian Amazon. Journal of Parasitology, v. 96, n. 6, p. 1089-1101, 2010a. doi: http://dx.doi.org/10.1645/GE-2539.1.

NIERI-BASTOS, F. A.; LOPES, M. G.; CANÇADO, P. H.; ROSSA, G. A.; FACCINI, J. L.; GENNARI, S. M.; LABRUNA, M. B. Candidatus Rickettsia andeanae, a spotted fever group agent infecting Amblyomma parvum ticks in two Brazilian biomes. Memórias do Instituto Oswaldo Cruz, v. 109, n. 2, p. 259-261, 2014. doi: http://dx.doi.org/10.1590/0074-0276140283.

NORTE, A. C.; RAMOS, J. A.; GERN, L.; NÚNCIO, M. S.; CARVALHO, I. L. Birds as reservoirs for Borrelia burgdorferi s.l. in Western Europe: circulation of B. turdi and other genospecies in bird-tick cycles in Portugal. Environmental Microbiology, v. 15, n. 2, p. 386-339, 2013. doi: http://dx.doi.org/10.1111/j.1462-2920.2012.02834.x.

NOVAKOVA, M.; LITERAK, I.; CHEVEZ, L.; MARTINS, T. F.; OGRZEWALSKA, M.; LABRUNA, M. B. Rickettsial infections in ticks from reptiles, birds and humans in Honduras. Ticks and Tick-borne Diseases, v. 6, n. 6, p. 737-742, 2015. doi: http://dx.doi.org/10.1016/j.ttbdis.2015.06.009.

OGDEN, N. H.; LINDSAY, L. R.; HANINCOVÁ, K.; BARKER, I. K.; BIGRAS-POULIN, M.; CHARRON, D. F.; HEAGY, A.; FRANCIS, C. M.; O'CALLAGHAN, C. J.; SCHWARTZ, I.; THOMPSON, R. A. Role of migratory birds in introduction and range expansion of Ixodes scapularis ticks and of Borrelia burgdorferi and Anaplasma phagocytophilum in Canada. Applied and Environmental Microbiology, v. 74, n. 6, p. 1780-1790, 2008. doi: http://dx.doi.org/10.1128/AEM.01982-07.
OGRZEWALSKA, M.; LITERAK, I.; CAPEK, M.; SYCHRA, O.; CALDERÓN, V. A.; RODRÍGUEZ, B. C.; PRUDENCIO, C.; MARTINS, T. F.; LABRUNA, M. B. Bacteria of the genus Rickettsia in ticks (Acari: Ixodidae) collected from birds in Costa Rica. Ticks and Tick- borne Diseases, v. 6, n. 4, p. 478-482, 2015. doi: http://dx.doi.org/10.1016/j.ttbdis.2015.03.016.

OGRZEWALSKA, M.; LITERAK, I.; CARDENASCALlIRGOS, J. M.; CAPEK, M.; LABRUNA, M. B. Rickettsia bellii in ticks Amblyomma varium Koch, 1844, from birds in Peru. Ticks and Tick-borne Diseases, v. 3, n. 4, p. 254-256, 2012b. doi: http://dx.doiorg/10.1016/j.ttbdis.2012.05.003.

OGRZEWALSKA, M.; LITERAK, I.; MARTINS, T. F.; LABRUNA, M. B. Rickettsial infections in ticks from wild birds in Paraguay. Ticks and Tick-borne Diseases, v. 5, n. 2, p. 83-89, 2014. doi: http:/dx.doi.org/10.1016/j.ttbdis2013.08.004.

OGRZEWALSKA, M.; MARTINS, T.; CAPEK, M.; LITERAK, I.; LABRUNA, M.B. A Rickettsia parkeri-like agent infecting Amblyomma calcaratum nymphs from wild birds in Mato Grosso do Sul, Brazil. Ticks and Tick Borne Diseases, v. 4, n. 1-2, p. 145- 147, 2013. doi: http://dx.doi.org/10.1016/j.ttbdis.2012.07.001.

OGRZEWALSKA, M.; PACHECO, R. C.; UEZU, A.; RICHTZENHAIN, L. J.; FERREIRA, F.; LABRUNA, M. B. Ticks (Acari: Ixodidae) infesting birds in an Atlantic rain forest region of Brazil. Journal of Medical Entomology, v, 46 , n. 5, p. 1225-1229, 2009a. doi: http://dx.doi.org/10.1603/033.046.0534.

OGRZEWALSKA, M.; PACHECO, R. C.; UEZU, A.; RICHTZENHAIN, L. J.; FERREIRA, F.; LABRUNA, M. B. Rickettsial infection in Amblyomma nodosum ticks (Acari: Ixodidae) from Brazil. Annals of Tropical Medicine and Parasitology, v. 103, n. 5, p. 413-425, 2009b. doi: http://dx.doi.org/10.1179/136485909X451744.

OGRZEWALSKA, M.; PACHECO, R.; UEZU, A.; FERREIRA, F.; LABRUNA, M.B. Ticks (Acari: Ixodidae) infesting wild birds in an Atlantic Forest area in the state of São Paulo, Brazil, with isolation of Rickettsia from the tick Amblyomma longirostre. Journal of Medical Entomology, v. 45, n. $4,770-774,2008$.

OGRZEWALSKA, M.; SARAIVA, D. G.; MORAES-FILHO, J.; MARTINS, T. F.; COSTA, F. B.; PINTER, A.; LABRUNA, M. B. Epidemiology of Brazilian spotted fever in the Atlantic Forest, state of São Paulo, Brazil. Parasitology, v. 139, n. 10, p. 1283-1300, 2012a. doi: http://dx.doi.org/10.1017/S0031182012000546. 
OGRZEWALSKA, M.; UEZU, A.; JENKINS, C. N.; LABARUNA, M. B. Effect of Forest fragmentation on tick infestations of birds and tick infection rates by Rickettsia in the Atlantic Forest of Brazil. EcoHealth, v. 8, n. 3, p. 320331, 2011b. doi: http://dx.doi.org/10.1007/s10393-011-0726-6.

OGRZEWALSKA, M.; UEZU, A.; LABRUNA, M. B. Ticks (Acari: Ixodidae) infesting wild birds in the eastern Amazon, northern Brazil, with notes on rickettsial infection in ticks. Parasitology Research, v. 106, n. 4, p. 809-816, 2010. doi: http://dx.doi.org/10.1007/s00436-010-1733-1.

OGRZEWALSKA, M.; UEZU, A.; LABRUNA, M. B. Ticks (Acari: Ixodidae) infesting wild birds in the Atlantic Forest in northeastern Brazil, with notes on rickettsial infection in ticks. Parasitology Research, v. 108, n. 3, p. 665-670, 2011 a. doi: http://dx.doi.org/10.1007/s00436-010-2111-8.

OlIVEIRA, B. O.; BELlUCI, M. S. P.; PORTZ, C.; OLIVEIRA, J. R. J. G.; DORETTO, J. R. L.; ORSI, M. A.; MAZUR, C.; ANDRADE, C. M. Biological characterization of M33 field isolate of Newcastle Disease virus. Virus Reviews and Research, v. 5, n. 2, p. 56, 2000.

OLSEN, B.; DUFFY, D. C.; JAENSON, T. G. T.; GYLFE, Å; BONNEDAHL, J.; BERGSTROM, S. Transhemispheric exchange of Lyme disease spirochetes by seabirds. Journal of Clinical Microbiology, v. 33, n. 12, p. 3270-3274, 1995b.

OLSEN, B.; JAENSON, T. G. T.; BERGSTRÖM, S. Prevalence of Borrelia burgdorferi sensu lato-infected ticks on migrating birds. Applied and Environmental Microbiology, v. 61, n. 8, p. 3082-3087, 1995a.

OLSEN, B.; JAENSON, T. G. T.; NOPPA, L.; BUNIKIS, J.; BERGSTRÖM, S. A Lyme borreliosis cycle in seabirds and Ixodes uriae ticks. Nature, v. 362, p. 340-342, 1993. doi: http://dx.doi.org/10.1038/362340a0.

OMETTO, T.; DURIGON, E. L.; DE ARAUJO, J.; APRELON, R.; DE AGUIAR, D. M.; CAVALCANTE, G. T.; MELO, R. M.; LEVI, J. E. de; DE AZEVEDO JÚNIOR, S. M.; PETRY, M. V.; NETO, I. S.; SERAFINI, P.; VILLALOBOS, E.; CUNHA, E. M.; LARA, LARA, M. C. C. S. H; NAVA, A. F.; NARDI, M. S.; HURTADO, R.; RODRIGUES, R.; SHERER, A. L.; SHERER, J. D. E. F.; GERALDI, M. P.; DE SEIXAS, M. M.; PETERKA, C.; BANDEIRA, D. D. E. S.; PRADEL, J.; VACHIERY, N.; LABRUNA, M. B.; DE CAMARGO, L. M.; LANCIOTTI, R.; LEFRANÇOIS, T. West Nile virus surveillance, Brazil 20082010. Transactions of the Royal Society of Tropical Medicine and Hygiene, v. 107, n. 11, p. 723-730, 2013. doi: http://dx.doi.org/10.1093/trstmh/trt081.
ORSI, M. A.; DORETTO, J. R L.; CAMILlO, S. C. A.; REISCHAK, D.; RIBEIRO, S. A. M.; RAMAZZOTI, A; MENDONCA, A. O.; SPILKI, F. R.; BUZINARO, M. G.; FERREIRA, H. L.; ARNS, C. W. Prevalence of newcastle disease virus in broiler chickens (Gallus gallus) in Brazil. Brazilian Journal of Microbiology, v. 41, n. 2, p. 349-357, 2010. doi: http://dx.doi.org/10.1590/S1517-83822010000200014.

PACHECO, R. C.; ARZUA, M.; NIERI-BASTOS, F. A.; MORAES-FILHO, J.; MARCILI, A.; RICHTZENHAIN, L. J.; BARROS-BATTESTI, D. M.; LABRUNA, M. B. Rickettsial infection in ticks (Acari: Ixodidae) collected on birds in southern Brazil. Journal of Medical Entomology, v. $49, \quad$ n. $3, \quad$ p. $710-716,2012$. doi: http://dx.doi.org/10.1603/ME11217.

PACHECO, R. C.; HORTA, M. C.; PINTER, A.; MORAESFILHO, J.; MARTINS, T. F.; NARDI, M. S.; SOUZA, S. S.; SOUZA, C. E.; SZABÓ, M. P.; RICHTZENHAIN, L. J.; LABRUNA, M. B. Pesquisa de Rickettsia spp em carrapatos Amblyomma cajennense e Amblyomma dubitatum no Estado de São Paulo. Revista da Sociedade Brasileira de Medicina Tropical, v, 42, n. 3, p. 351-353, 2009. doi: http://dx.doi.org/10.1590/S0037-86822009000300023.

PACHECO, R. C.; MORAES-FILHO, J.; NAVA, S.; BRANDAO, P. E.; RICHTZENHAIN, L. J.; LABRUNA, M. B. Detection of a novel spotted fever group rickettsia in Amblyomma parvum ticks (Acari: Ixodidae) from Argentina. Experimental and Applied Acarology, v. 43, n. 1, p. 63-71, 2007. doi: http://dx.doi.org/10.1007/s10493007-9099-5.

PACHECO, R. C.; ROSA, S.; RICHTZENHAIN, L.; SZABÓ, M. P. J.; LABRUNA, M. B. Isolation of Rickettsia bellii from Amblyomma ovale and Amblyomma incisum ticks from southern Brazil. Revista MVZ Córdoba, v. 13, n. 2, p. 1273-1279, 2008.

PACHECO, R. C.; VENZAL, J. M.; RICHTZENHAIN, L. J.; LABRUNA, M. B. Rickettsia parkeri in Uruguay. Emerging Infectious Diseases, v. 12, p. 1804-1805, 2006.

PADDOCK, C. D.; FOURNIER, P. E.; SUMNER, J. W.; GODDARD, J.; ELSHENAWY, Y.; METCALFE, M. G.; LOFTIS, A. D., VARELA-STOKES, A. Isolation of Rickettsia parkeri and iden-tification of a novel spotted fever group Rickettsia sp. from Gulf Coast ticks (Amblyomma maculatum) in the United States. Applied and Environmental Microbiology, v. 76, n. 9, p. 26892696, 2010.

PADDOCK, C. D.; SUMNER, J. W.; COMER, J. A.; ZAKI, S. R.; GOLDSMITH, C. S.; GODDARD, J.; MCLELLAN, S. 
L. F.; TAMMINGA, C. L.; OHL, C. A. Rickettsia parkeri: a newly recognized cause of spotted fever rickettsiosis in the United States. Clinical Infectious Diseases, v. 38, n. 6, p. 805-811, 2004.

PARKER, R. R.; PHILIP, C. B.; JELLISON, W. L. Rocky Mountain spotted fever: Potentialities of tick transmission in relation to geographical occurrence in the United States. American Journal of Tropical Medicine and Hygiene, v. 13, p. 341-378, 1933.

PAROLA, P.; MATSUMOTO, K.; SOCOLOVSCHI, C.; PARZY, D.; RAOULT, D. A tick-borne rickettsia of the spotted-fever group, similar to Rickettsia amblyommii, in French Guyana. Annals of Tropical Medicine and Parasitology, v. 101, n. 2, 185-188, 2007.

PAROLA, P.; PADDOCK, C. D.; SOCOLOVSCHI, C.; LABRUNA, M. B.; MEDIANNIKOV, O.; KERNIF, T.; ABDAD, M. Y.; STENOS, J.; BITAM, I.; FOURNIER, P. E.; RAOULT, D. Update on tick-borne rickettsioses around the world: a geographic approach. Clinical Microbiology Reviews, v. 26, n. 4, p. 657-702, 2013.

PASCOAL, J. O.; AMORIM, M. P.; MARTINS, M. M.; MELO, C.; SILVA JÚNIOR, E. L.; OGRZEWASLKA, M.; LABRUNA, M. B.; SZABÓ, M. P. J. Ticks on birds in a savanna (Cerrado) reserve on the outskirts of Uberlândia, Minas Gerais, Brazil. Revista Brasileira de Parasitologia Veterinária, v. 22, n. 1, p. 46-52, 2013. doi: http://dx.doi.org/10.1590/S1984-29612013005000004.

PIACENTINI, V. Q.; ALEIXO, A.; AGNE, C. E.; MAURÍCIO, G. N.; PACHECO, J. F.; BRAVO, G. A.; BRITO, G. R. R.; NAKA, L. N.; OLMOS, F.; POSSO, S.; SILVEIRA, L. F.; BETINI, G. S.; CARRANO, E.; FRANZ, I.; LEES, A. C.; LIMA, L. M.; PIOLI, D.; SCHUNCK, F.; AMARAL, F. R.; BENCKE, G. A.; COHN-HAFT, M.; FIGUEIREDO, L. F. A.; STRAUBE F. C.; CESARI, E. Annotated checklist of the birds of Brazil by the Brazilian Ornithological Records Committee. Revista Brasileira de Ornitologia, v. 23, n. 2, p. 91-298, 2015.

PINTER, A.; DIAS, R. A.; GENNARI, S. M.; LABRUNA, M. B. Study of the seasonal dynamics, life cycle, and host specificity of Amblyomma aureolatum (Acari: Ixodidae). Journal of Medical Entomology, v. 41, n. 3, p. 324-332, 2004. doi: http://dx.doi.org/10.1603/0022-2585-41.3.324

PINTER, A.; HORTA, M. C.; PACHECO, R. C.; MORAESFILHO, J.; LABRUNA, M. B. Serosurvey for Rickettsia spp in dogs and humans from a Brazilian spotted fever endemic area in the state of São Paulo. Cadernos de Saúde Pública, v. 24, n. 2, p. 247-252, 2008.
PINTER, A.; LABRUNA, M. B. Isolation of Rickettsia rickettsii and Rickettsia bellii in cell culture from the tick Amblyomma aureolatum in Brazil. Annals of the New York Academy of Sciences, v. 1078, p. 523-529, 2006.

RAMOS, D. G. S.; MELO, A. L. T.; MARTINS, T. F.; ALVES, A. S.; PACHECO, T. A.; PINTO, L. B.; PINHO, J. B.; LABRUNA, M. B.; DUTRA, V.; AGUIAR, D. M.; PACHECO, R. C. Rickettsial infection in ticks from wild birds from Cerrado and the Pantanal region of Mato Grosso, Midwestern, Brazil. Ticks and Tick-borne Diseases, v. 6, n. 6, p. 836-842, 2015. doi: http://dx.doi.org/10.1016/j.ttbdis.2015.07.013.

RAND, P. W.; LACOMBE, E. H.; SMITH JR., R. P.; FLICKER, J. Participation of birds (Aves) in the emergence of Lyme disease in southern Maine. Journal of Medical Entomology, v. 35, n. 3 p. 270-276, 1998. doi: http://dx.doi.org/10.1093/jmedent/35.3.270.

RANDOLPH, S. E. Ticks are not insects: consequences of contrasting vector biology for transmission potential. Parasitology Today, v. 14, n. 5, p. 186-92, 1998.

RAOULT, D.; ROUX, V. Rickettsioses as paradigms of new or emerging infectious diseases. Clinical Microbiology Reviews, v. 10, n. 4, p. 694-719, 1997.

RALPH, C. J.; GEUPEL, G. R.; PYLE, P.; MARTIN, T. E.; DESANTE, D. F.; MILÁ, B. Manual de métodos de campo para el monitoreo de aves terrestres. Albany, CA: Pacific Southwest Research Station, Forest Service, U.S. Department of Agriculture, 1996.

SABATINI, G. S.; PINTER, A.; NIERI-BASTOS, F. A.; MARCILI, A.; LABRUNA, M. B. Survey of ticks (Acari: Ixodidae) and their rickettsia in an Atlantic rain forest reserve in the State of São Paulo, Brazil. Journal of Medical Entomology, v. 47, n. 5, p. 913-916, 2010. doi: http://dx.doi.org/10.1603/ME10073.

SANCHES, G. S.; MARTINS, T. F.; LOPES, I. T.; COSTA, L. F. S.; NUNES, P. H.; CAMARGO-MATHIAS, M. I.; LABRUNA, M. B. Ticks infesting birds in Atlantic Forest fragments in Rio Claro, State of São Paulo, Brazil. Revista Brasileira de Parasitologia Veterinária, v. 22, n. 1, p. 6-12, $2013 . \quad$ doi: http://dx.doi.org/10.1590/S198429612013000100003

SANTOLIN, I. D. A. C.; LUZ, H. R.; ALCHORNE, N. M.; PINHEIRO, M. C.; MELINSKI, R. D.; FACCINI, J. L. H.; FERREIRA, I; FAMADAS, K. M.Ticks on birds caught on the campus of the Federal Rural University of Rio de Janeiro, Brazil. Revista Brasileira de Parasitologia 
Veterinária, v. 21, n. 3, p. 213-218, 2012. doi: http://dx.doi.org/10.1590/S1984-29612012000300007.

SANTOS-SILVA, M. M.; SOUSA, R.; SANTOS, A. S.; MELO, P.; ENCARNAÇÃO, V.; BACELLAR, F. Ticks Parasitizing Wild Birds in Portugal: Detection of Rickettsia aeschlimannii, R. helvetica and R. massiliae. Experimental and Applied Acarology, v. 39, n. 3-4, p. 331-338, 2006. doi: http://dx.doi.org/10.1007/s10493-006-9008-3.

SARAIVA, D. G.; FOURNIER, G. F.; MARTINS, T. F.; LEAL, K. P.; VIEIRA, F. N.; CÂMARA, E. M.; COSTA, C. G.; ONOFRIO, V. C.; BARROS-BATTESTI, D. M.; GUGLIELMONE, A. A.; LABRUNA, M. B. Ticks (Acari:Iixodidae) associated with small terrestrial mammals in the state of Minas Gerais, southeastern Brazil. Experimenal and Applied Acarology, v. 58, n. 2, p. 159166, 2012. doi: http://dx.doi.org/10.1007/s10493-012-9570-9.

SARAIVA, D. G.; NIERI-BASTOS, F. A.; HORTA, M. C.; SOARES, H. S.; NICOLA, P. A.; PEREIRA, L. C.; LABRUNA, M. B. Rickettsia amblyommii Infecting Amblyomma auricularium ticks in Pernambuco, Northeastern Brazil: isolation, transovarial transmission, and transstadial perpetuation. Vector-Borne and Zoonotic Diseases, v. 13, n. 9, p. 615-618, 2013. doi: http://dx.doi.org/10.1089/vbz.2012.1223.

SCOFIELD, A.; BAHIA, M.; MARTINS, A. L.; GÓESCAVALCANTE, G.; MARTINS, T. F.; LABRUNA, M. B. Amblyomma dissimile Koch (Acari: Ixodidae) Atacking Primolius maracana Vieillot (Psitaciformes: Psitacidae) in the Amazon Region, State of Pará, Brazil. Neotropical Entomology, v. 40, n. 4, p. 509-511, 2011. doi: http://dx.doi.org/10.1590/S1519-566X2011000400017.

SCOTT, J. D.; ANDERSON, J. F.; DURDEN, L. A. Widespread dispersal of Borrelia burgdorferi-Infected ticks collected from songbirds across Canada. Journal of Parasitology, v. 98, n. 1, p. 49-59, 2012. doi: http://dx.doi.org/10.1645/GE-2874.1.

SCOTT, J. D.; DURDEN, L. A. First record of Amblyomma rotundatum tick (Acari: Ixodidae) parasitizing a bird collected in Canada. Systematic and Applied Acarology, v. 20, n. 2, p. 155-161, 2015. doi: http:/dx.doi.org/10.11158/saa.202.1.

SCOTT, J. D.; DURDEN, L. A.; ANDERSON, J. F. Infection prevalence of Borrelia burgdorferi in ticks collected from songbirds in Far-Western Canada. Open Journal of Animal Sciences, v. 5, n. 3, p. 232-241, 2015. doi: http://dx.doi.org/10.4236/ojas.2015.53027.
SCOTT, J. D.; FERNANDO, K.; BANERJEE, S. N.; DURDEN, L. A.; BYRNE, S. K.; BANERJEE, M.; MANN, R. B.; MORSHED, M. G. Birds disperse ixodid (Acari: Ixodidae) and Borrelia burgdorferi-infected ticks in Canada. Journal of Medical Entomology, v. 38, n. 4, p. 493-500, 2001. doi: http://dx.doi.org/10.1603/0022-2585-38.4.493.

SCOTT, J. D.; LEE, M. K.; FERNANDO, K.; DURDEN, L. A.; JORGENSEN, D. R.; MAK, S.; MORSHED, M. G. Detection of Lyme disease spirochete, Borrelia burgdorferi sensu lato, including three novel genotypes in ticks (Acari: Ixodidae) collected from songbirds (Passeriformes) across Canada. Journal of Vector Ecology, v. 35, n. 1, p. 124-139, 2010. doi: http://dx.doi.org/10.1111/j.1948-7134.2010.00068.x.

SICK, H. Ornitologia brasileira. Rio de Janeiro: Nova Fronteira, 1997. 912 p.

SILVA, N.; EREMEEVA, M. E.; ROZENTAL, T.; RIBEIRO, G. S.; PADDOCK, C. D.; RAMOS, E. A. G.; FAVACHO, A. R.; REIS, M. G.; DASCH, G. A.; DE LEMOS, E. R.; KO, A. I. Eschar-associated spotted fever rickettsiosis, Bahia, Brazil. Emerging Infectious Diseases, v. 17, n. 2, p. 275-278, 2011. doi: http://dx.doi.org/10.3201/eid1702.100859.

SILVEIRA, I.; MARTINS, T. F.; OLEGÁRIO, M. M.; PETERKA, C.; GUEDES, E.; FERREIRA, F.; LABRUNA, M. B. Rickettsial infection in animals, humans and ticks in Paulicéia, Brazil. Zoonoses and Public Health, v. 62, n. 7, p. 525-533, 2015, doi: http://dx.doi.org/10.1111/zph.12180.

SILVEIRA, I.; PACHECO, R. C.; SZABO, M. P. J.; RAMOS, H. G. C.; LABRUNA, M. B.; Rickettsia parkeri in Brazil. Emerging Infectious Diseases, v. 13, n. 7, p. 1111-1113, 2007.

SILVEIRA, J. A. G.; OLIVEIRA, P. A.; CURI, N. H. A.; BARATA, R. S. L.; CHIARELLO, A. G.; RIBEIRO, M. F. B. Ocorrência de Amblyomma longirostre (Koch, 1844) em Chaetomys subspinosus (Olfers, 1818) oriundos da Mata Atlântica. Arquivo Brasileiro de Medicina Veterinária e Zootecnia, v. 60 , n. 3, p. 772-774, 2008. doi: http://dx.doi.org/10.1590/S0102-09352008000300038.

SMITH, M. P.; PONNUSAMY, L.; JIANG, J.; AYYASH, L. A.; RICHARDS, A. L.; APPERSON, C. S. Bacterial pathogens in Ixodid ticks from a Piedmont County in North Carolina: prevalence of rickettsial organisms. Vector-Borne and Zoonotic Diseases, v. 10, n. 10, p. 939952, 2010. doi: http://dx.doi.org/10.1089/vbz.2009.0178.

SMITH JR., R. P.; RAND, P. W.; LACOMBE, E. H.; MORRIS, S. R.; HOLMES, D. W.; CAPORALE, D. A. Role of bird migration in the long-distance dispersal of Ixodes dammini, the vector of Lyme disease. Journal of Infectious 
Diseases, v. $174, \quad$ n. $1, \quad$ p. 221-224, 1996 doi: http://dx.doi.org/10.1093/infdis/174.1.221.

SMITH, R. P.; MUZAFFAR, S. B.; LAVERS, J.; LACOMBE, E. H.; CAHILL, B. K.; LUBELCZYK, C. B.; KINSLER, A.; MATHERS, A. J.; RAND, P. W. Borrelia garinii in Seabird Ticks (Ixodes uriae), Atlantic Coast, North America. Emerging Infectious Diseases, v. 12, n. 12, p. 1909-1912, 2006.

SOARES, J. F.; SOARES, C. D. M.; GALLIO, M.; DA SILVA, A. S.; MOREIRA, J. P.; BARROS-BATTESTI, D. M.; MONTEIRO, S. G. Occurrence of Amblyomma longirostre in Ramphastos dicolorus in Southern Brazil. Ciência Rural, v. 39, n. 3, p. 930-932, 2009. doi: http://dx.doi.org/10.1590/S0103-84782009005000012.

SPENCER, R. The ringer's manual. $2^{\text {nd }}$ ed. Tring: British Trust Ornithology, 1972. p. 28-42.

SPOLIDORIO, M. G.; LABRUNA, M. B.; MANTOVANI, E.; BRANDAO, P. E.; RICHTZENHAIN, L. J.; YOSHINARI, N. H. Novel spotted fever group rickettsiosis, Brazil. Emerging Infectious Diseases, v. 16, n. 3, p. 521523, 2010. doi: http://dx.doi.org/10.3201/eid1603.091338.

SPONCHIADO, J.; MELO, G. L.; MARTINS, T. F.; KRAWCZAK, F. S.; LABRUNA, M. B.; CÁCERES, N. C. Association patterns of ticks (Acari: Ixodida: Ixodidae, Argasidae) of small mammals in Cerrado fragments, western Brazil. Experimental and Applied Acarology, v. 65, n. 3, p. 389-401, 2015. doi: http://dx.doi.org/10.1007/s10493-014-9877-9.

STAFFORD, K. C.; BLADEN, C. V.; MAGNARELLI, L. A. Ticks (Acari: Ixodidae) infesting wild birds (Aves) and white-footed mice in Lyme, CT. Journal of Medical Entomology, v. 32, n. 4, p. 453-466, 1995 . doi: http://dx.doi.org/10.1093/jmedent/32.4.453.

STROMDAHL, E. Y.; VINCE, M. A.; BILLINGSLEY, P. M.; DOBBS, N. A.; WILLIAMSON, P. C. Rickettsia amblyommii infecting Amblyomma americanum larvae. Vector-Borne and Zoonotic Diseases, v. 8, n. 1, p. 15-24, 2008. http://dx.doi.org/10.1089/vbz.2007.0138.

SZABÓ, M. P. J.; CASTRO, M. B.; RAMOS, H. G. C.; GARCIA, M. V.; CASTAGNOLLI, K. C. A.; PINTER, A.; VERONEZ, V. A.; MAGALHÃES, G. M.; DUARTE, J. M. B.; LABRUNA, M. B. Species diversity and seasonality of free-living ticks (Acari: Ixodidae) in the natural habitat of wild marsh deer (Blastocerus dichotomus) in Southeastern Brazil. Veterinary Parasitology, v, 143, n. 2, p. 147-154, 2007b. doi: http://dx.doi.org/10.1016/j.vetpar.2006.08.009.
SZABO, M. P. J.; LABRUNA, M. B.; CASTAGNOLLI, K. C.; GARCIA, M. V.; PINTER, A.; VERONEZ, V. A.; MAGALHÃES, G. M.; CASTRO, M. B.; VOGLIOTTIAL, A. Ticks (Acari: Ixodidae) parasitizing humans in an Atlantic rainforest reserve of Southeastern Brazil with notes on host suitability. Experimental and Applied Acarology, v. 39, n. 3-4,p.339-346, 2006. doi: http://dx.doi.org/10.1007/s10493-006-9013-6.

SZABÓ, M. P. J.; LABRUNA, M. B.; GARCIA, M. V.; PINTER, A.; CASTAGNOLLI, K. C.; PACHECO, R. C.; CASTRO, M. B.; VERONEZ, V. A.; MAGALHAES, G. M.; VOGLIOTTI, A.; DUARTE, J. M. B. Ecological aspects of the free-living ticks (Acari: Ixodidae) on animal trails within Atlantic rainforest in south-eastern Brazil. Annals of Tropical Medicine and Parasitology, v. 103, n. 1, p. 57-72, 2009. doi: http://dx.doi.org/10.1179/136485909X384956.

SZABÓ, M. P. J.; LABRUNA, M. B.; PEREIRA, M. C.; DUARTE, J. M. B. Ticks (Acari: Ixodidae) on wildmarshdeer (Blastocerus dichotomus) from southeast Brazil: infestations before and after habitat loss. Journal of Medical Entomology, v. 40, n. 3, p. 268-274. 2003. doi: http://dx.doi.org/10.1093/jmedent/40.3.268.

SZABÓ, M. P. J.; PASCOLI, G. V. T.; MARÇAL JÚNIOR, O.; FRANCHIN, A. G.; TORGAN, K. Brown dog tick Rhipicephalus sanguineus parasitizing the bird Coereba flaveola in the Brazilian Cerrado. Ciência Rural, v. 38, n. 2, p. 543-545, 2008. doi: http://dx.doi.org/10.1590/S010384782008000200041 .

SZABÓ, M. P. J.; PINTER, A.; LABRUNA, M. B. Ecology, biology and distribution of spotted-fever tick vectors in Brazil. Frontiers in Cellular and Infection Microbiology, v. 3,n. 27,p. 1-9,2013b. doi:http://dx.doi.org/10.3389/fcimb.2013.00027.

SZABÓ, M. P.; NIERI-BASTOS, F. A.; SPOLIDORIO, M. G.; MARTINS, T. F.; BARBIERI, A. M.; LABRUNA, M. B. In vitro isolation from Amblyomma ovale (Acari: Ixodidae) and ecological aspects of the Atlantic rainforest Rickettsia, the causative agent of a novel spotted fever rickettsiosis in Brazil. Parasitology, v. 140, n. 6, p. 719-728, 2013a. doi: http://dx.doi.org/10.1017/S0031182012002065.

SZABÓ, M. P.; OLEGÁRIO, M. M.; SANTOS, A. L. Tick fauna from two locations in the Brazilian savannah. Experimental and Applied Acarology, v. 43, n. 1, p. 73-84, 2007a. doi: http://dx.doi.org/10.1007/s10493-007-9096-8.

TEIXEIRA, R. H. F.; FERREIRA, I.; AMORIM, M.; GAZÊTA, G. S.; SERRA-FREIRE, N. M. Carrapatos em aves selvagens no Zoológico de Sorocaba - São Paulo, Brasil. Arquivo Brasileiro de Medicina Veterinária e Zootecnia, 
v. $60, \quad$ p. 1277-1280, 2008 doi: http://dx.doi.org/10.1590/S0102-09352008000500037.

THOMAZELLI, L. M.; ARAUJO, J. de.; FERREIRA, C. S.; HURTADO, R.; OLIVEIRA, D. B.; OMETTO, T.; GOLONO, M.; SANFILIPPO, L.; DEMETRIO, C.; FIGUEIREDO, M. L.; DURIGON, E. L. Molecular surveillance of the Newcastle disease virus in domestic and wild birds on the North Eastern Coast and Amazon biome of Brazil. Revista Brasileira de Ciência Avícola, v. 14, n.1, p. 1-7, 2012. doi: http://dx.doiorg/10.1590/S1516-635X2012000100001.

TOLESANO-PASCOLI, G. V.; TORGA, K.; FRANCHIN, A. G.; OGRZEWALSKA, M.; GERARDI, M.; OLEGÁRIO, M. M.; LABRUNA, M. B.; SZABÓ, M. P.; MARCAL JÚNIOR, O. J. Ticks on birds in a forest fragment of Brazilian cerrado (savanna) in the municipality of Uberlândia, State of Minas Gerais, Brazil. Revista Brasileira de Parasitologia Veterinária, v. 19, n. 4, p. 244-248, 2010. doi: http://dx.doi.org/10.1590/S1984-29612010000400010.

TOLESANO-PASCOLI, G.; GARCIA, F. I.; GOMES, C. R. G.; DINIZ, K. C.; ONOFRIO, V. C.; VENZAL, J. M.; SZABÓ, M. P. J. Ticks (Acari: Ixodidae) on swifts (Apodiformes: Apodidae) in Minas Gerais, southeastern Brazil. Experimental and Applied Acarology, v. 64, n. 2, p. 259-263, 2014. doi: http://dx.doi.org/10.1007/s10493-014-9797-8. TOMASSONE, L.; CONTE, V.; PARRILLA, G.; MENEGHI, D. Rickettsia infection in dogs and Rickettsia parkeri in Amblyomma tigrinum ticks, Cochabamba Department, Bolivia. Vector-Borne and Zoonotic Diseases, v. 10, n. 10, p. 953-958, 2010b. doi: http://dx.doi.org/10.1089/vbz.2009.0126.

TOMASSONE, L.; NUÑEZ, P.; CEBALLOS, L. A.; GÜRTLER, R. E., KITRON, U.; FARBER, M. Detection of "Candidatus Rickettsia sp. strain Argentina" and Rickettsia bellii in Amblyomma ticks (Acari: Ixodidae) from Northern Argentina. Experimental and Applied Acarology, v. 52, n. 1, p. 93-100, 2010a. doi: http://dx.doiorg/10.1007/s10493-010-9339-y.

TORGA, K.; TOLESANO-PASCOLI, G.; VASQUEZ, J. B.; SILVA JUNIOR, E. L.; LABRUNA, M. B.; MARTINS, T. F.; OGRZEWALSKA, M.; SZABÓ, M. P. J. Ticks on birds from Cerrado forest patches along the Uberabinha river in the Triângulo Mineiro region of Minas Gerais, Brazil. Ciência Rural, v. 43, n. 10, p. 1852-1857, 2013 . doi: http://dx.doi.org/10.1590/S0103-84782013005000121.

TROUT, R.; STEELMAN, C. D.; SZALANSKI, A. L.; WILLIAMSON, P. C. Rickettsiae in Gulf Coast Ticks, Arkansas, USA. Emerging Infectious Diseases, v. 16, n. 5, p. 830-832, 2010. doi: http://dx.doi.org/10.3201/eid1605.091314.
VENZAL, J. M.; AUTINO, A. G.; NAVA, S.; GUGLIELMONE, A. A. Ornithodoros mimon Kohls, Clifford and Jones, 1969 (Acari: Argasidae) on Argentinean bats, and new records from Uruguay. Systematic and Applied Acarology, v. 9, n. 1, p. 37-39, 2004a. doi: http://dx.doi.org/10.11158/saa.9.1.7.

VENZAL, J. M.; ESTRADA-PEÑA, A.; CASTRO, O.; SOUZA, C. G.; FÉLIX, M. L.; NAVA, S.; GUGLIELMONE, A. A. Amblyomma triste Koch, 1844 (Acari: Ixodidae): hosts and seasonality of the vector of Rickettsia parkeri in Uruguay. Veterinary Parasitology, v. 155, n. 1-2, p. 104109, 2008. doi: http://dx.doi.org/10.1016/j.vetpar.2008.04.017.

VENZAL, J. M.; ESTRADA-PEÑA, A.; PORTILLO, A.; MANGOLD, A. J.; CASTRO, O.; SOUZA, C. G.; FÉLIX, M. L.; PÉREZ-MARTÍNEZ, L.; SANTIBÁNEZ, S.; OTEO, J. A. Rickettsia parkeri: a Rickettsial pathogen transmitted by ticks in endemic areas for spotted fever rickettsiosis in southern Uruguay. Revista do Instituto de Medicina Tropical de São Paulo, v. 54, n. 3, p. 131-134, 2012. doi: http://dx.doi.org/10.1590/S0036-46652012000300003.

VENZAL, J. M.; FÉLIX, M. L.; OLMOS, A.; MANGOLD, A. J.; GUGLIELMONE, A. A. A collection of ticks (Ixodidae) from wild birds in Uruguay. Experimental and Applied Acarology, v. 36, n. 4, p. 325-331, 2005. doi: http://dx.doi.org/10.1007/s10493-005-8433-z.

VENZAL, J. M.; PORTILLO, A.; ESTRADA-PEÑA, A.; CASTRO, O.; CABRERA, P. A.; OTEO, J. A. Rickettsia parkeri in Amblyomma triste from Uruguay. Emerging Infectious Diseases, v. 10, n. 8, p. 1493-1495, 2004b. doi: http://dx.doi.org/10.3201/eid1008.030999.

VEST, E. D.; LUNDGREN, D. L.; PARKER, D. D.; JOHNSON, D. E.; MORSE, E. L.; BUSHMAN, J. B.; SIDWELL, R. W.; THORPE, B. D. Results of a five-year survey for certain enzootic diseases in the fauna of western Utah. American Journal of Tropical Medicine and Hygiene, v. 14, n. 1, p. 124-135, 1965.

WANG, Y.; FINCH, D. M. Consistency of mist netting and point counts in assessing landbird species richness and relative abundance during migration. The Condor, v. 104, n. 1, p. 59-72, 2002. doi: http://dx.doi.org/10.1650/00105422(2002)104[0059:COMNAP]2.0.CO;2.

WHITMAN, T. J.; RICHARDS, A. L.; PADDOCK, C. D.; TAMMINGA, C. L.; SNIEZEK, P. J.; JIANG, J.; BYERS, D. K.; SANDERS, J. W. Rickettsia parkeri infection after tick bite, Virginia. Emerging Infectious Diseases, v. 13, n. 2, p. 334-336, 2007. doi: http://dx.doi.org/10.3201/eid1302.061295. 
WILLIAMSON, P. C.; BILLINGSLEY, P. M.; TELTOW, G. J.; SEALS, J. P.; TURNBOUGH, M. A.; ATKINSON, S. F. Borrelia, Ehrlichia, and Rickettsia spp. in ticks removed from persons, Texas, USA. Emerging Infectious Diseases, v. 16, n. 3, p.441-446, 2010. doi: http://dx.doi.org/10.3201/eid1603.091333.

WITTER, R.; MARTINS, T. F.; CAMPOS A. K.; MELO, A. L. T.; CORRÊA, S. H. R.; MORGADO, T. O.; WOLF, R. W.; MAY-JÚNIOR, J. A.; SINKOC, A. L.; STRÜSSMANN, C.; AGUIAR, D. M.; ROSSI, R. V.; SEMEDO, T. B. F.; CAMPOS, Z.; DESBIEZ, A. L. J.; LABRUNA, M. B.;
PACHECO, R. C. Rickettsial infection in ticks (Acari: Ixodidae) of wild animals in midwestern Brazil. Ticks and Tick-borne Diseases, v. 7, n. 3, p. 415-423, 2016. doi: http://dx.doi.org/10.1016/j.ttbdis.2015.12.019.

ZERINGÓTA, V.; MATURANO, R.; SANTOLIN, Í. D.; MCINTOSH, D.; FAMADAS, K. M.; DAEMON, E.; FACCINI, J. L. New host records of Haemaphysalis leporispalustris (Acari: Ixodidae) on birds in Brazil. Parasitology Research, p. 1-4, 2016. doi: http://dx.doi.org/10.1007/s00436-016-4978-5. 